OPEN ACCESS

Edited by:

Florent Allais,

AgroParisTech Institut des Sciences et Industries du Vivant et de L'environnement, France

Reviewed by:

Sarbjit S. Giddey,

Commonwealth Scientific and Industrial Research Organisation

(CSIRO), Australia

Aniruddha Pramod Kulkarni,

Commonwealth Scientific and Industrial Research Organisation

(CSIRO), Australia

Emilia Morallon,

University of Alicante, Spain Andre Heel,

Zurich University of Applied Sciences, Switzerland

${ }^{*}$ Correspondence: Jerry J. Kaczur jerry.kaczur@dioxidematerials.com Richard I. Masel rich.masel@dioxidematerials.com

Specialty section: This article was submitted to Chemical Engineering, a section of the journal Frontiers in Chemistry

Received: 27 March 2018 Accepted: 12 June 2018 Published: 03 July 2018

Citation:

Kaczur JJ, Yang H, Liu Z, Sajjad SD and Masel RI (2018) Carbon Dioxide and Water Electrolysis Using New Alkaline Stable Anion Membranes.

Front. Chem. 6:263. doi: 10.3389/fchem.2018.00263

\section{Carbon Dioxide and Water Electrolysis Using New Alkaline Stable Anion Membranes}

\author{
Jerry J. Kaczur*, Hongzhou Yang, Zengcai Liu, Syed D. Sajjad and Richard I. Masel* \\ Dioxide Materials Inc., Boca Raton, FL, United States
}

The recent development and market introduction of a new type of alkaline stable imidazole-based anion exchange membrane and related ionomers by Dioxide Materials is enabling the advancement of new and improved electrochemical processes which can operate at commercially viable operating voltages, current efficiencies, and current densities. These processes include the electrochemical conversion of $\mathrm{CO}_{2}$ to formic acid $(\mathrm{HCOOH}), \mathrm{CO}_{2}$ to carbon monoxide $(\mathrm{CO})$, and alkaline water electrolysis, generating hydrogen at high current densities at low voltages without the need for any precious metal electrocatalysts. The first process is the direct electrochemical generation of pure formic acid in a three-compartment cell configuration using the alkaline stable anion exchange membrane and a cation exchange membrane. The cell operates at a current density of $140 \mathrm{~mA} / \mathrm{cm}^{2}$ at a cell voltage of $3.5 \mathrm{~V}$. The power consumption for production of formic acid (FA) is about $4.3-4.7 \mathrm{kWh} / \mathrm{kg}$ of $\mathrm{FA}$. The second process is the electrochemical conversion of $\mathrm{CO}_{2}$ to $\mathrm{CO}$, a key focus product in the generation of renewable fuels and chemicals. The $\mathrm{CO}_{2}$ cell consists of a two-compartment design utilizing the alkaline stable anion exchange membrane to separate the anode and cathode compartments. A nanoparticle $\mathrm{IrO}_{2}$ catalyst on a GDE structure is used as the anode and a GDE utilizing a nanoparticle Ag/imidazolium-based ionomer catalyst combination is used as a cathode. The $\mathrm{CO}_{2}$ cell has been operated at current densities of 200 to $600 \mathrm{~mA} / \mathrm{cm}^{2}$ at voltages of 3.0 to 3.2 respectively with $\mathrm{CO}_{2}$ to $\mathrm{CO}$ conversion selectivities of $95-99 \%$. The third process is an alkaline water electrolysis cell process, where the alkaline stable anion exchange membrane allows stable cell operation in $1 \mathrm{M} \mathrm{KOH}$ electrolyte solutions at current densities of $1 \mathrm{~A} / \mathrm{cm}^{2}$ at about $1.90 \mathrm{~V}$. The cell has demonstrated operation for thousands of hours, showing a voltage increase in time of only $5 \mu \mathrm{V} / \mathrm{h}$. The alkaline electrolysis technology does not require any precious metal catalysts as compared to polymer electrolyte membrane (PEM) design water electrolyzers. In this paper, we discuss the detailed technical aspects of these three technologies utilizing this unique anion exchange membrane.

Keywords: anion exchange membranes, electrochemical, formic acid, carbon monoxide, $\mathrm{CO}_{2}$ utilization, alkaline water electrolysis 


\section{INTRODUCTION}

Over the past decade, increasing interest has been directed in utilizing carbon dioxide in generating liquid fuels and chemicals as a means toward a sustainable, carbon-neutral based economy. The efficient generation of energy-dense carbon-based products from captured and anthropogenic $\mathrm{CO}_{2}$ using renewable energy sources such as solar energy, wind, nuclear, and hydroelectric provides the basis for sourcing sustainable chemical feedstocks that are not derived from fossil fuels (Halmann, 1993; Aresta and Dibenedetto, 2007; Aresta, 2010; Whipple and Kenis, 2010; Quadrelli et al., 2011; Sankaranarayanan and Srinivasan, 2012; Hu et al., 2013; Masel et al., 2014a, 2016a; Aresta et al., 2016).

The efficient generation of carbon monoxide (CO) from $\mathrm{CO}_{2}$ is one of the key focus areas in producing sustainable chemical feedstocks. It is an industrially valuable chemical that is typically produced from methane, producing various mixture ratios of $\mathrm{CO}$ and hydrogen, called syngas. Syngas is used in the manufacture of fuels, such as diesel and gasoline, as well as other chemicals via Fischer-Tropsch (F-T) chemistry using selected catalysts and operating conditions (Appel, 2013; Costentin et al., 2014; Masel et al., 2014a, 2016a; Liu et al, 2015).

The generation of renewable hydrogen is the other key renewable energy product focus area. Hydrogen is used in many industrial processes and a component of the "Hydrogen Economy" concept. It is a way of storing and generating renewable energy that can be used as a fuel for automobiles and other applications (Ursua et al., 2012; U.S. Department of Energy (DOE), 2018).

\section{NEW ALKALINE STABLE ANION MEMBRANES}

Dioxide Materials (DM) has developed a group of novel imidazole-functionalized membranes using a polystyrene-based backbone that are surprisingly stable in strong alkaline solutions (Masel et al., 2017a,b,c). These membranes are now available for researchers for developing other process applications. Details on these membranes are provided in the next sections.

\section{Sustainion ${ }^{\circledR}$ Pre-polymer and Anion Membrane Description}

The anion exchange Sustanion ${ }^{\circledR}$ membranes are based on a cheap and abundant, but more importantly, alkaline stable polystyrene backbone. The polymer synthesis and subsequent fabrication of the membrane have been described in detail in several past publications (Masel et al., 2016b, 2017d; Kutz et al., 2017; Liu et al., 2017a; Sajjad et al., 2017). The synthesis involves a two-step process (Figure 1) of copolymerization followed by subsequent functionalization. The membrane can be cast as a film or as a reinforced membrane using various reinforcement materials. The chloride form of the membrane is then typically converted to the hydroxide form using $\mathrm{KOH}$.

Briefly, a copolymer of styrene and vinyl benzyl chloride is prepared by free radical addition polymerization. The copolymer product is then washed and precipitated in ethanol. Afterwards, it is filtered, dried and subsequently functionalized with 1,2,4,5-tetramethylimidazole in a Dowanol ${ }^{\circledR}$ PM (1-methoxy-2 propanol) solvent. Divinylbenzene is also added as a crosslinker to help improve membrane strength. The cast membrane is then activated for $8-16 \mathrm{~h}$ in a $1 \mathrm{M}$ potassium hydroxide solution for conversion to the hydroxide form.

\section{Membrane Production Scale-Up}

The synthetic route for the ionomer shown in Figure 1 has been ramped up to industrial sized reactor volumes and transferred to a commercial size pilot coater for membrane manufacturing. A membrane production run typically produces several hundred to a thousand feet of membrane having a width of about $24 \mathrm{~cm}$. The final width and total membrane footage can be altered according to customer requirements.

\section{Anion Membrane Properties}

The anion exchange membranes are typically supplied in a dry, chloride form supported on a polyethylene terephthalate (PET) liner. They consequently have to be converted to the hydroxide form by exposing them to a strong base. DM recommends soaking the membrane in a large bath of $1 \mathrm{M} \mathrm{KOH}$ for 24$48 \mathrm{~h}$ in order to convert the membrane chloride form into the hydroxide form. This activation also helps in strengthening the membrane via crosslinking with $\mathrm{KOH}$ as identified in a recent nuclear magnetic spectroscopy (NMR) study (Pellerite et al., 2017). Furthermore, during this process the membrane swells and separates from the PET liner, which is discarded.

The membrane has an ion exchange capacity (IEC) of $\sim 1.1$ $\mathrm{mmol} / \mathrm{g}$ calculated through standard back titration technique (Vengatesan et al., 2015). Even more impressive is the area specific resistance (ASR) of the membrane. Table 1 shows that the measured normalized resistance for Sustanion ${ }^{\circledR} 37-50$ at the same alkaline conditions is more than an order lower than the other commercially available membranes. The anion exchange membrane has shown excellent performance ability in multiple cell runs of $1,000-3,000 \mathrm{~h}$ and more of run time in electrochemical cell testing in a wide $\mathrm{pH}$ range as exemplified in published experimental carbon dioxide and alkaline water electrolyzer data (Masel et al., 2016b; Kutz et al., 2017; Liu et al., 2017a,b; Sajjad et al., 2017). Some of the latest results are highlighted in later sections of this paper.

The Sustainion ${ }^{\circledR}$ anion exchange membranes undergo moderate swelling, about $5 \%$ in lateral directions and about $50 \%$ in thickness during conversion to the hydroxide form using $1 \mathrm{M} \mathrm{KOH}$. This membrane swelling or high-water uptake ( $\sim 80 \%)$ explains the low area specific resistance (ASR) (i.e., high ionic conductivity) measurement values, as water absorption seems an important mechanism for hydroxide ion transport. Recognizing the need for more dimensionally stable and robust membranes, DM has now been also producing more robust reinforced versions of the Sustanion ${ }^{\circledR}$ anion exchange membranes, suitable for use in larger electrolyzers and more demanding electrochemical applications. The reinforcement support makes these membranes stronger in both the wet and dry states. 


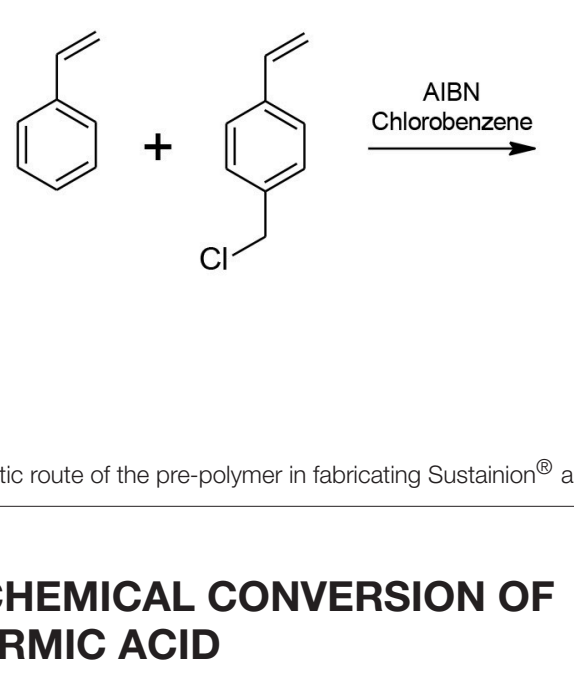

Numerous researchers over the past 30 years have been examining the performance of various catalysts in the electrochemical reduction conversion of $\mathrm{CO}_{2}$ to formate/formic acid. Various papers have provided excellent summary reviews on previous experimental work (Jitaru, 2007; Rosen et al., 2011; Lu et al., 2014; Qiao et al., 2014; Pletcher, 2015; Du, 2017) and will not be further described here. More recently, a number of investigators have gone one step further, conducting and reporting studies providing performance data on complete electrochemical $\mathrm{CO}_{2}$ cell conversion performance in producing formate/formic acid (Mahmood et al., 1987; Li and Oloman, 2005, 2006, 2007; Oloman and Li, 2008; Whipple et al., 2010; Agarwal et al., 2011; Alvarez-Guerra et al., 2012, 2014; Kopljar et al., 2014; White et al., 2014; Du et al, 2016; Sen et al., 2016).

DM has been able to successfully produce high concentrations of pure formic acid directly in an electrochemical cell from the electrochemical reduction of $\mathrm{CO}_{2}$ (Kaczur et al., 2017; Yang et al., $2017 a, b)$. This reduces the need for acid conversion of alkali metal formate salt-based products (e.g., potassium formate) which are typically produced using these alternative electrochemical cell and process configurations.

\section{Formic Acid (FA) Cell Design}

The DM electrochemical formic acid cell configuration is based on a three-compartment design consisting of an anode compartment, a center flow compartment containing a cation ion exchange media where the formic acid product is collected and removed from the cell, and a cathode compartment where the electrochemical reduction of $\mathrm{CO}_{2}$ to formate ions occurs (Kaczur et al., 2017; Yang et al., 2017a,b).

The general electrochemical formic acid cell configuration is shown in Figure 2A. The anode compartment utilizes an MMO (mixed metal oxide) coated titanium anode where deionized water is electrolyzed producing oxygen and hydrogen ions $\left(\mathrm{H}^{+}\right)$. A cation ion exchange membrane adjoining the anode compartment is used to block the transport of formate anions to the anode, where it would be oxidized to $\mathrm{CO}_{2}$. The formed hydrogen ions pass through the cation exchange membrane into the center flow compartment. The preferred
TABLE 1 | Area specific resistance (ASR) measurements of Sustanion 37-50 and other commercial ion exchange membranes in $1 \mathrm{M} \mathrm{KOH}$ at $60^{\circ} \mathrm{C}$.

\begin{tabular}{|c|c|c|}
\hline Membrane & $\begin{array}{l}\text { ASR in } 1 \mathrm{M} \mathrm{KOH} \text { at } \\
60^{\circ} \mathrm{C}\left(\Omega-\mathrm{cm}^{2}\right)\end{array}$ & $\begin{array}{c}\text { Membrane Operational } \\
\text { pH Range (Mfg. Spec } \\
\text { Sheet) }\end{array}$ \\
\hline Sustainion® $37-50$ & 0.045 & $2-14$ \\
\hline Nafion® N115 & 0.52 & $0-13$ \\
\hline Fumasep FAPQ-375 & 0.83 & $0-11$ \\
\hline AMl-7001 & 2.0 & $0-10$ \\
\hline PBI (polybenzimidazole) & 8.3 & $2-10$ \\
\hline Neosepta@ ACN & $>50$ & $0-8$ \\
\hline
\end{tabular}

design cation membrane is a perfluorinated sulfonic acid type membrane which is both oxidation stable and efficient in blocking formate anion transport. The anolyte uses a deionized water anolyte since the anode-membrane has a zero-gap contact arrangement.

In the cathode compartment, $\mathrm{CO}_{2}$ is efficiently reduced at low overpotentials to formate using a tin nanoparticle and imidazole-based ionomer catalyst coating combination in a carbon GDE (gas diffusion electrode) structure. The formate ions produced, as well as hydroxide and bicarbonate/carbonate ions that are formed, then pass through the adjoining Sustainion ${ }^{\circledR}$ anion exchange membrane into the center flow compartment.

In the center flow compartment, a cation ion exchange media is used to provide the solution conductivity needed for the formic acid product that is being formed in the compartment. Formate ions formed in the cathode compartment pass through the adjoining Sustainion ${ }^{\circledR}$ anion membrane and combine with the hydrogen ions transporting through the cation exchange membrane from the anode compartment to form a pure formic acid product. Deionized water metered into the center flow compartment is used to collect and remove the formic acid product from the compartment. The formic acid concentration depends on the input water flowrate into the center flow compartment and the operating cell current, forming a formic acid end product at concentrations that can range from 2 to $30 \mathrm{wt} \%$ and at high Faradaic efficiencies of 85 to $95 \%$. Any hydroxide ions entering the center flow 

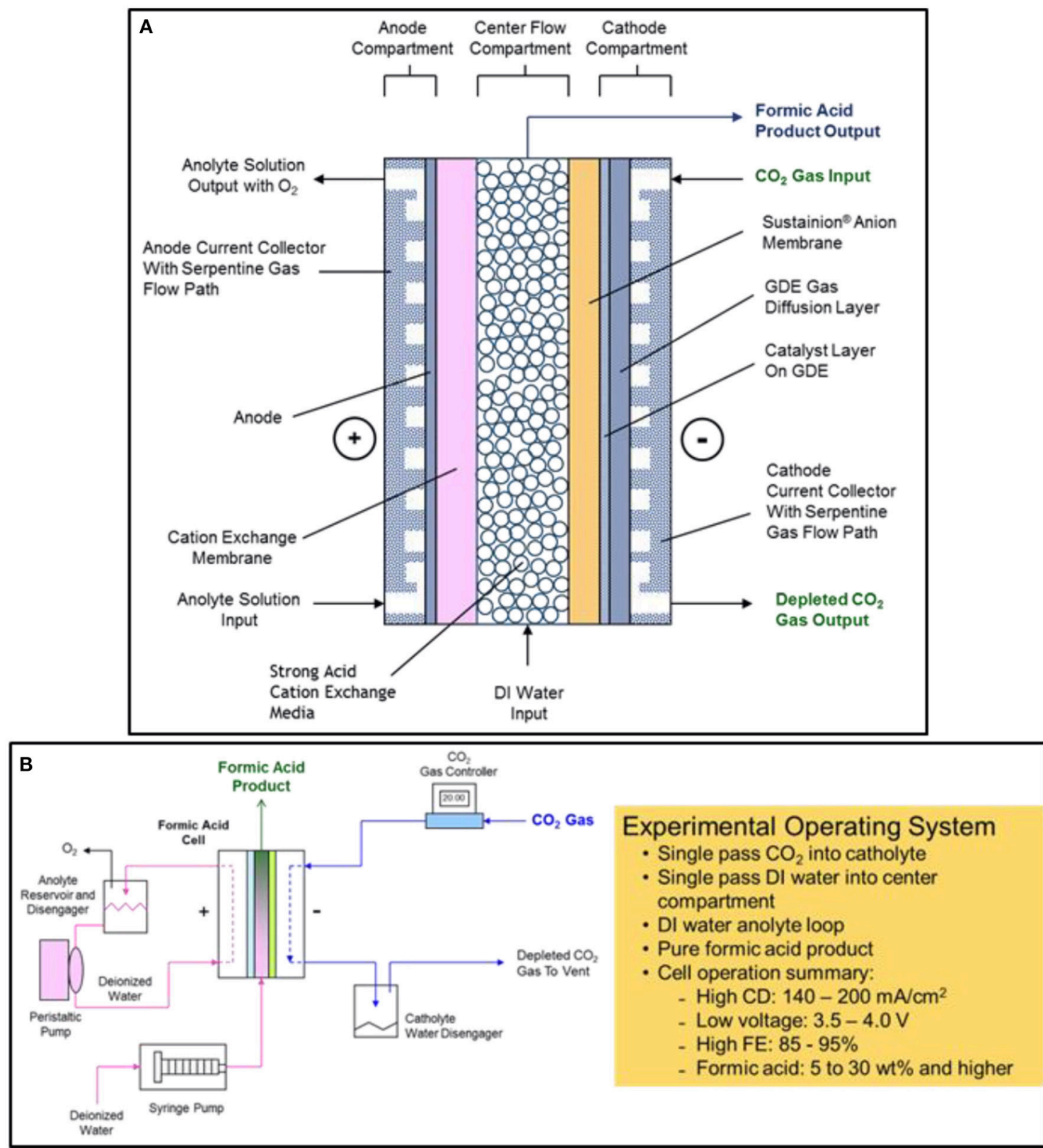

FIGURE 2 | The electrochemical three compartment formic acid cell design configuration is shown in (A). The experimental formic acid cell operating system and performance summary is shown in (B).

compartment react with hydrogen ions to form water, and any bicarbonate/carbonate ion transport will react with the hydrogen ions to form $\mathrm{CO}_{2}$, exiting with the formic acid product as gaseous $\mathrm{CO}_{2}$. The cation ion exchange media used in the design, Amberlite ${ }^{\circledR}$ IR120 hydrogen form cation ion exchange resin beads, provided improved ionic conductivity in the center flow compartment since formic acid solutions have a significantly lower conductivity. The cation exchange media provided a lower operating cell voltage (Yang et al., 2017a).

\section{Formic Acid Cell Experimental Operating System}

Figure 2B shows a schematic of the experimental formic acid cell operating system as well as a brief summary of the cell operating performance. The cell produced formic acid concentrations of between 5 to $30 \%$ depending on the single pass flow rate of DI water feed into the center compartment. The FA cell operating current density range is from 140 to $200 \mathrm{~mA} \mathrm{~cm}-2$ at corresponding cell voltages of 3.5 and 4.0 volts operating at room temperature. The Faradaic cell efficiency ranged from 80 
to $95 \%$ when utilizing a Nafion ${ }^{\circledR} 324$ cation exchange membrane and a Sustainion ${ }^{\circledR}$ 37-50 anion exchange membrane in the cell configuration (Yang et al., 2017a).

\section{Formic Acid Cell Chemistry}

The formic acid (FA) cell has a complex set of reactions that occur at the anode, the GDE cathode, and the center flow compartment that is bounded by a cation exchange membrane on the anode side and an anion exchange membrane on the cathode side. Figure 3 shows the proposed main and secondary reactions as well as ion transport that may occur during cell operation.

\section{Formic Acid Cell Main Reactions}

The electrochemical reduction of $\mathrm{CO}_{2}$ occurs in the presence of water at the cathode, forming formate $\left(\mathrm{HCOO}^{-}\right)$and hydroxide $\left(\mathrm{OH}^{-}\right)$ions:

$$
\mathrm{CO}_{2}+\mathrm{H}_{2} \mathrm{O}+2 \mathrm{e}^{-} \rightarrow \mathrm{HCOO}^{-}+\mathrm{OH}^{-}
$$

Simultaneously, the oxidation of water occurs at the anode, forming oxygen gas and hydrogen ions $\left(\mathrm{H}^{+}\right)$. Hydrogen ions are actually hydronium or oxonium cations $\left(\mathrm{H}_{3} \mathrm{O}^{+}\right)$in aqueous solutions, and in this paper we are using $\mathrm{H}^{+}$as the substitute for hydronium ions.

$$
2 \mathrm{H}_{2} \mathrm{O} \rightarrow 4 \mathrm{H}^{+}+4 \mathrm{e}^{-}+\mathrm{O}_{2}
$$

Both formate ions and hydroxide ions migrate through the anion exchange membrane into the center flow compartment, where they combine with hydrogen ions produced in the anode compartment passing through the cation membrane to yield water and formic acid as follows:

$$
\begin{array}{r}
\mathrm{H}^{+}+\mathrm{OH}^{-} \rightarrow \mathrm{H}_{2} \mathrm{O} \\
\mathrm{H}^{+}+\mathrm{HCOO}^{-} \rightarrow \mathrm{HCOOH}
\end{array}
$$

\section{Formic Acid Cell Side Reactions}

Side reactions that can occur at the cathode and catholyte are as follows:

$$
\begin{array}{r}
\mathrm{CO}_{2}+\mathrm{H}_{2} \mathrm{O}+2 \mathrm{e}^{-} \rightarrow \mathrm{CO}+2 \mathrm{OH}^{-} \\
2 \mathrm{H}_{2} \mathrm{O}+2 \mathrm{e}^{-} \rightarrow \mathrm{H}_{2}+2 \mathrm{OH}^{-} \\
\mathrm{CO}_{2}+\mathrm{OH}^{-} \rightarrow \mathrm{HCO}_{3}^{-}
\end{array}
$$

Bicarbonate $\left(\mathrm{HCO}_{3}^{-}\right)$anions formed at the cathode layer migrate through the anion exchange membrane into the center flow compartment, reacting with hydrogen ions entering the center flow compartment from the anode compartment through the adjoining cation membrane to produce $\mathrm{CO}_{2}$ :

$$
\mathrm{H}^{+}+\mathrm{HCO}_{3}^{-} \rightarrow \mathrm{CO}_{2}+\mathrm{H}_{2} \mathrm{O}
$$

Formic acid product will be lost if it transports through the cation membrane into the anolyte compartment, being subsequently oxidized at the anode to $\mathrm{CO}_{2}$ :

$$
\mathrm{HCOOH} \rightarrow \mathrm{CO}_{2}+2 \mathrm{H}^{+}+2 \mathrm{e}^{-}
$$

\section{Formic Acid Cell Performance}

Reference (Yang et al., 2017a) provides detailed performance information of the 3-compartment formic acid cell. Figure 4 shows the performance data for the $5 \mathrm{~cm}^{2} 3$-compartment formic acid cell having a cell configuration utilizing an $\mathrm{IrO}_{2}$ coated titanium sintered fiber anode on a titanium flow field, Nafion ${ }^{\circledR}$ 324 cation membrane, and Sustanion ${ }^{\circledR}$ 37-50 anion exchange membrane operating at a current density of $140 \mathrm{~mA} / \mathrm{cm}^{2}$. Table 2 provides the detailed cell configuration information. The cell was operated for about $142 \mathrm{~h}$, producing a formic acid product concentration increasing from about 8.1 to $9.4 \% \mathrm{w} \%$, and operating at a Faradaic efficiency of $80 \%$ at the start and at $94 \%$ near the end of the run until it was shutdown for inspection. No deterioration of the cell anode/cathode components was noted. The key in obtaining high FA Faradaic efficiency was employing a Nafion ${ }^{\circledR} 324$ cation membrane, which minimized the transport of formate/formic acid ions into the anolyte compartment.

The calculated formic acid cell design power consumption is in the range of 4.3-4.7 DC kWh/kg FA at these ambient operating conditions. This corresponds to an electrical operating cost of $\$ 214-\$ 232$ per ton of FA using a power cost of $\$ 0.05 / \mathrm{kWh}$.

\section{Future Scale-Up and Formic Acid Product Applications}

The worldwide market for formic acid and the commercial chemical production route as well some product applications are shown in Figure 5A.

A sustainable route in producing formic acid from renewable energy resources is shown in Figure 5B. The various FA product applications include silage/food, chemicals, energy storage, and fuels. The use of formic acid as a feedstock in biological reactors, replacing sugars and/or agricultural grains, is another promising feedstock route.

DM is currently working with industrial partners in scaling up the electrochemical formic acid technology.

\section{ELECTROCHEMICAL $\mathrm{CO}_{2}$ ELECTROLYSIS: CONVERSION OF $\mathrm{CO}_{2}$ TO CO}

Interest in the development of process methods of converting $\mathrm{CO}_{2}$ to a commercially useful and valuable product such as $\mathrm{CO}$ has been increasing over the last 20 years. $\mathrm{CO}$ in combination with hydrogen is the basis for the Fischer-Tropsch (F-T) process that is capable of producing a wide variety of fuels and chemicals. One important research area is using electrochemical processing in the conversion of $\mathrm{CO}_{2}$ to $\mathrm{CO}$. Some of the research work in this area has been summarized in several review papers (Appel, 2013; Costentin et al., 2014; Masel et al., 2014a, 2016b).

The development of the DM-based $\mathrm{CO}_{2}$ electrolyzer technology in efficiently producing $\mathrm{CO}$ at high selectivities is based on three technological improvements. These are:

- Development of a GDE cathode structure comprising an imidazole-based ionomer as a co-catalyst with nanoparticle $\mathrm{Ag}$, reducing the potential at the cathode for the $\mathrm{CO}_{2}$ reduction reaction to $\mathrm{CO}$. 


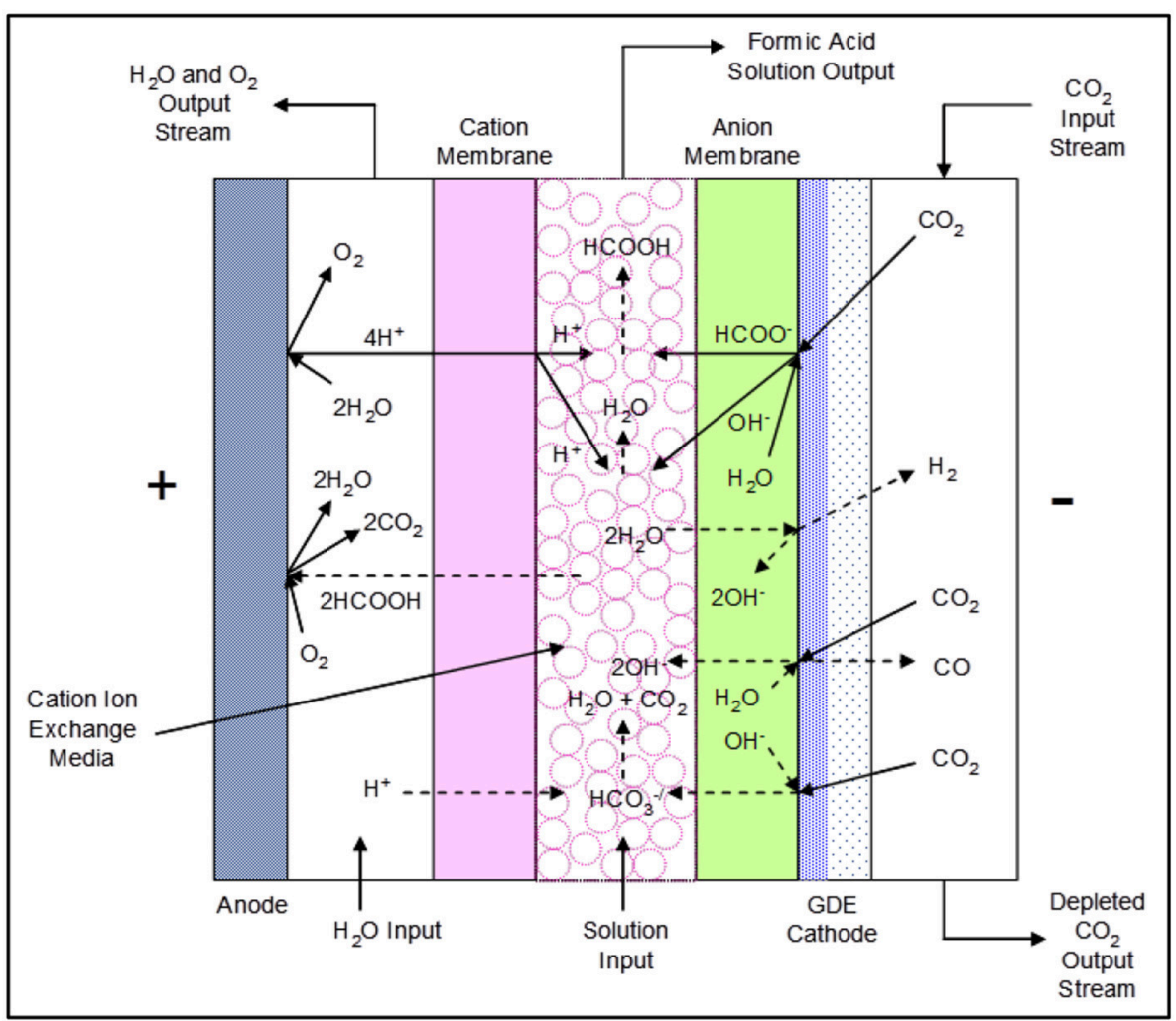

FIGURE 3 | The DM 3-compartment formic acid cell configuration showing proposed reactions and ion transport.

- Development of a high conductivity and alkaline stable anion membrane (Sustainion ${ }^{\circledR}$ membrane) that can conduct $\mathrm{OH}^{-}$ and bicarbonate/carbonate ions.

- Development of a GDE anode structure comprising a nanoparticle $\mathrm{IrO}_{2}$ catalyst that is stable for more than 3,000 h of operation.

All of these developments have helped create an electrochemical $\mathrm{CO}_{2}$ technology that can simultaneously operate at high current densities, high CO selectivity, and low cell potentials. Much of the recent work on the $\mathrm{CO}_{2}$ electrolysis technology are summarized in various papers and patents (Masel et al., 2014b, 2015; 2016c Masel and Rosen, 2014; Masel and Chen, 2015). Some of the aspects of the $\mathrm{CO}_{2}$ electrolyzer design, technology improvements, and performance are described in the next few sections.

\section{$\mathrm{CO}_{2}$ Electrolysis Cell Design}

The basic $\mathrm{DM} \mathrm{CO}_{2}$ electrolysis cell configuration is shown in Figure 6A. The cell design employs a titanium serpentine flow path anode current collector and a graphite or 316L stainless steel serpentine flow field cathode current collector. The GDE anode utilizes a nanoparticle $\mathrm{IrO}_{2}$ catalyst on a carbon paper support. The GDE cathode uses a nanoparticle Ag with Sustainion ${ }^{\circledR}$ imidazole-based ionomer catalyst combination on a carbon paper support that suppresses the formation of hydrogen at the

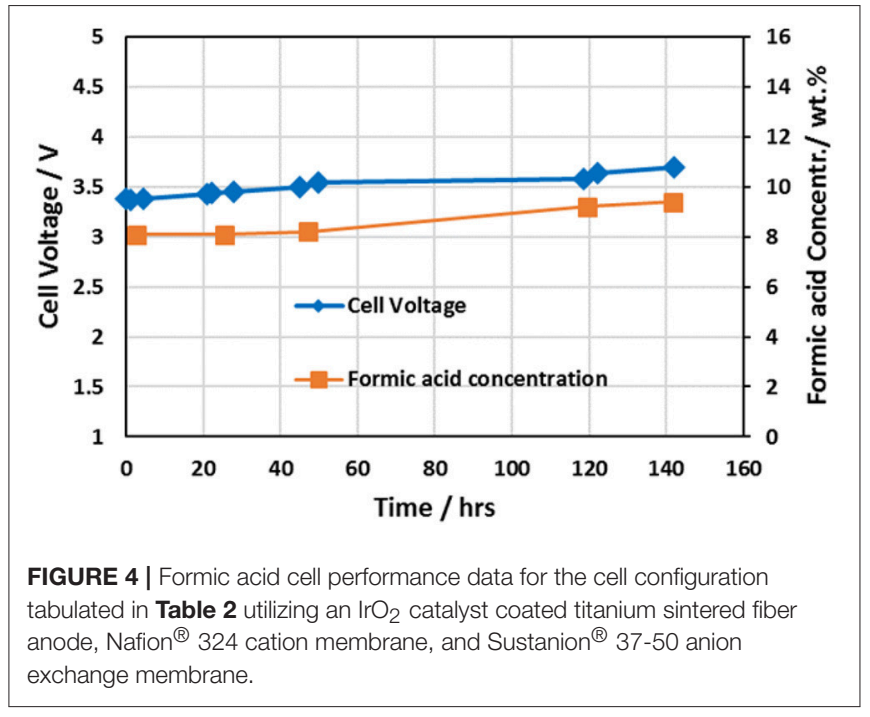

cathode, thus obtaining very high selectivities of 95 to $99 \%$ of $\mathrm{CO}_{2}$ to $\mathrm{CO}$.

\section{$\mathrm{CO}_{2}$ Cell Chemistry}

Figure 6B shows the main complex ion flow paths in the electrochemical $\mathrm{CO}_{2}$ cell. The $\mathrm{CO}_{2}$ cell operates using a dilute $10 \mathrm{mM}$ potassium bicarbonate solution anolyte and a humidified 
TABLE 2 | Formic acid cell 142 h extended run electrolyzer configuration.

\section{Anode}

$\mathrm{IrO}_{2}$ based thermal coating on titanium sintered fiber anode on a titanium serpentine flow field, DI water anolyte

\section{Cathode}

GDE, Nanoparticle Sn, Sn Loading: $5 \mathrm{mg} / \mathrm{cm}^{2}$

5 wt\% PTFE, 5 wt\% carbon black, 5wt \% imidazolium-based Sustainion ${ }^{\circledR}$ 37-50 ionomer $\mathrm{CO}_{2}$ gas flow rate: $20 \mathrm{~mL} / \mathrm{min}$

\section{Anion Membrane}

Dioxide Materials Sustainion ${ }^{\circledR}$ X37-50 imidazolium-based anion exchange membrane

\section{Cation Membrane}

Chemours Nafion ${ }^{\circledR}$ N324

Center Flow Compartment

Resin Fill: Amberlite ${ }^{\circledR}$ IRC 120 Hydrogen form, 620-830 $\mu \mathrm{m}$ bead size DI water single-pass mode input flow rate: $0.10 \mathrm{~mL} / \mathrm{min}$

Operating Temperature: Ambient

Operating Current: $0.7 \mathrm{amps}, \mathbf{C D}: 140 \mathrm{~mA} / \mathrm{cm}^{2}$

Cell Active Membrane Area: $5 \mathrm{~cm}^{2}$

$\mathrm{CO}_{2}$ gas catholyte stream. High $\mathrm{KHCO}_{3}$ anolyte concentrations can result in the precipitation of the potassium salts in the cathode GDE, resulting in $\mathrm{CO}_{2}$ gas flow blockage in the cathode serpentine flow path.

\section{$\mathrm{CO}_{2}$ Cell Cathode Reactions}

Below are the proposed cathode reactions in the $\mathrm{CO}_{2}$ cell. $\mathrm{CO}_{2}$ is reduced to $\mathrm{CO}$ on an $\mathrm{Ag}$ nanoparticle catalyst and formed hydroxide ions are transported through the anion exchange membrane or react with $\mathrm{CO}_{2}$ to form carbonate/bicarbonate anions which will also pass through the anion exchange membrane.

a. $\mathrm{CO}_{2}$ reduction reaction on nanoparticle $\mathrm{Ag}$ catalyst producing $\mathrm{CO}$ and hydroxide ions:

$$
\mathrm{CO}_{2}+\mathrm{H}_{2} \mathrm{O}+2 \mathrm{e}^{-} \rightarrow \mathrm{CO}+2 \mathrm{OH}^{-}-0.52 \mathrm{~V} \text { vs SHE @pH7 }
$$

b. $\mathrm{CO}_{2}$ reaction with hydroxide ions forming carbonate anions:

$$
\mathrm{CO}_{2}+2 \mathrm{OH}^{-} \rightarrow \mathrm{CO}_{3}^{-2}+\mathrm{H}_{2} \mathrm{O}
$$

c. $\mathrm{CO}_{2}$ reaction with hydroxide ions forming bicarbonate anions:

$$
\mathrm{CO}_{2}+\mathrm{OH}^{-} \rightarrow \mathrm{HCO}_{3}^{-}
$$

d. Carbonate ions further reaction with $\mathrm{CO}_{2}$ to form bicarbonate anions:

$$
\mathrm{CO}_{3}^{-2}+\mathrm{CO}_{2}+\mathrm{H}_{2} \mathrm{O} \rightarrow 2 \mathrm{HCO}_{3}^{-}
$$

e. Water reduction electrolysis side reaction producing both hydrogen gas and hydroxide ions:

$$
2 \mathrm{H}_{2} \mathrm{O}+2 \mathrm{e}-\rightarrow \mathrm{H}_{2}+2 \mathrm{OH}^{-}
$$

\section{$\mathrm{CO}_{2}$ Cell Anode Reactions}

Below are the proposed anode reactions in the $\mathrm{CO}_{2}$ cell. The anode reactions are complex and may be a set of mixed reactions. Water may be electrolyzed on the nanoparticle $\mathrm{IrO}_{2}$ oxidation catalyst forming oxygen and hydrogen ions with an alternate possible anode reaction being the electrolysis of hydroxide ions at the catalyst, forming oxygen and water. The presence of the carbonate/bicarbonate ions in the anolyte and their conversion to $\mathrm{CO}_{2}$ provides complex bulk solution buffering in the anolyte compartment.

a. Electrolysis of water on anode catalyst making oxygen and hydrogen ions at $\mathrm{pH} 7$ and $\mathrm{pH} 0$ :

$$
\begin{aligned}
& 2 \mathrm{H}_{2} \mathrm{O} \rightarrow \mathrm{O}_{2}+4 \mathrm{H}^{+}+4 \mathrm{e}^{-} 0.815 \mathrm{~V} \text { vs SHE @ } \mathrm{pH} 7 \\
& 2 \mathrm{H}_{2} \mathrm{O} \rightarrow \mathrm{O}_{2}+4 \mathrm{H}^{+}+4 \mathrm{e}^{-} 1.23 \mathrm{~V} \text { vs SHE @ } \mathrm{pH} 0
\end{aligned}
$$

b. Electrolysis of hydroxide ions on the anode catalyst forming oxygen and electrons:

$$
4 \mathrm{OH}^{-} \rightarrow \mathrm{O}_{2}+2 \mathrm{H}_{2} \mathrm{O}+2 \mathrm{e}^{-} 0.40 \mathrm{~V} \text { vs SHE @ } \mathrm{pH}
$$

c. Bicarbonate decomposition by hydrogen ions forming $\mathrm{CO}_{2}$ and water:

$$
\mathrm{HCO}_{3}^{-}+\mathrm{H}^{+} \rightarrow \mathrm{CO}_{2}+\mathrm{H}_{2} \mathrm{O}
$$

d. Carbonate decomposition by hydrogen ions forming $\mathrm{CO}_{2}$ and water:

$$
\mathrm{CO}_{3}^{-2}+2 \mathrm{H}^{+} \rightarrow \mathrm{CO}_{2}+\mathrm{H}_{2} \mathrm{O}
$$

e. Hydroxide ions reacting with hydrogen ions producing water:

$$
\mathrm{H}^{+}+\mathrm{OH}^{-} \rightarrow \mathrm{H}_{2} \mathrm{O}
$$

\section{Overall $\mathrm{CO}_{2}$ Cell Reactions-Determining If Bicarbonate and Carbonate Are the Predominant Mobile Ionic Current Carrier Species}

The complex ion transport in the $\mathrm{CO}_{2}$ cell is theorized to mainly consist of bicarbonate and carbonate anions as the predominant current carriers as well as any hydroxide anions that had not reacted with $\mathrm{CO}_{2}$ gas in the catholyte reactions at the GDE cathode. Experimental investigation of the ratios of the transport of these anion species in the cell and through the membrane have not yet been fully investigated. Testing of the DM $250 \mathrm{~cm}^{2}$ cell at LanzaTech (Skokie, IL) provided important data on the cell anolyte gas composition by GC. Table 3 shows some of the potential reactions based on (A) bicarbonate or (B) carbonate anion transport respectively in the cell. Net anode reaction (17) in Table 3A would predict that the anode gas composition should have a $\mathrm{CO}_{2}$ to $\mathrm{O}_{2}$ ratio of $4: 1$ or gas composition consisting of $80 \% \mathrm{CO}_{2}$ and $20 \% \mathrm{O}_{2}$ if bicarbonate was the only anion current carrier in the cell. Alternatively, net anode reaction (20) in Table 3B would predict a 2:1 ratio of $\mathrm{CO}_{2}$ to $\mathrm{O}_{2}$ or gas composition consisting of $67 \% \mathrm{CO}_{2}$ and $33 \% \mathrm{O}_{2}$ if carbonate was the only anion current carrier in the cell. 


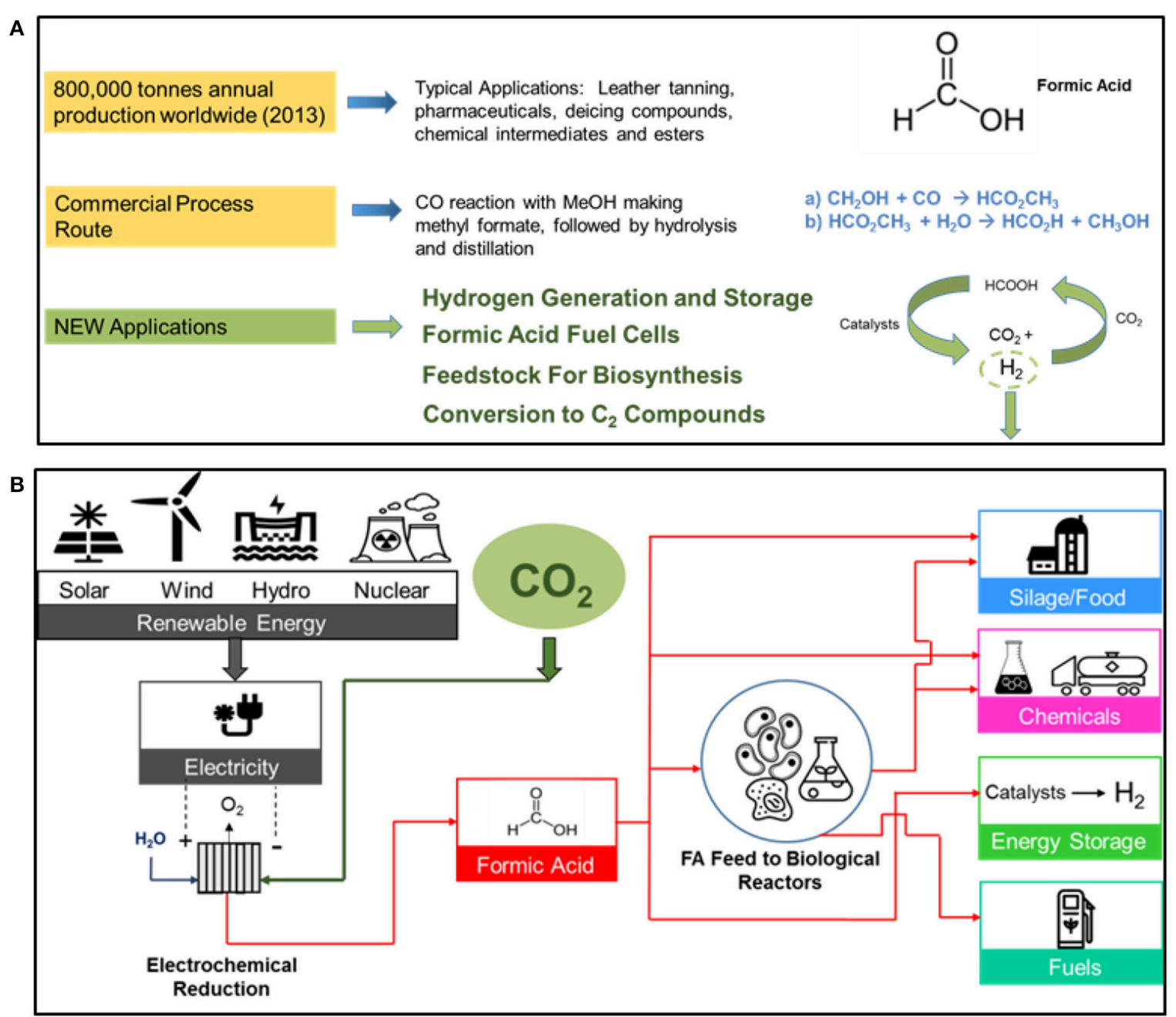

FIGURE 5 | The worldwide market for formic acid (2013) showing the current chemical commercial process route by the carbonylation of methanol, and some new FA applications is shown in (A). A sustainable route to formic acid using renewable energy resources and manufacturing products in the various product categories is shown in (B).

DM's measurement of the cell anode gas composition in the past had showed variability in $\mathrm{CO}_{2}$ content, ranging from 30 to $60 \%$ depending on the operating conditions of the cell. One GC gas analysis set of an operating $250 \mathrm{~cm}^{2} \mathrm{CO}_{2}$ cell at LanzaTech showed a gas composition as follows:

Anolyte Gas Product:

Catholyte Gas Product:

CO Selectivity:

$64 \% \mathrm{CO}_{2}, 33 \% \mathrm{O}_{2}$ by volume $39 \% \mathrm{CO}, 57 \% \mathrm{CO}_{2}, 0.34 \% \mathrm{H}_{2}$ $99.2 \%$

Catholyte $\mathrm{CO}_{2}$ Gas Feed Rate: $\quad 1,000 \mathrm{cc} / \mathrm{min}$

Operating Cell Current Density: $100 \mathrm{~mA} / \mathrm{cm}^{2}$ (25 Amps)

Operating Cell Voltage: $\quad 2.89 \mathrm{~V}$

The $\mathrm{CO}_{2}$ cell typically has a bulk anolyte $\mathrm{pH}$ of about 6.0 when operating on a $10 \mathrm{mM} \mathrm{KHCO}_{3}$ electrolyte, which is equivalent to a 50:50 mixture of carbonic acid $\left(\mathrm{H}_{2} \mathrm{CO}_{3}\right)$ and bicarbonate. These anolyte gas results point to carbonate ions as potentially being the main charge carrier because the $\mathrm{CO}_{2}: \mathrm{O}_{2}$ molar gas ratio was about $2: 1$. So the definitive answer to the predominant ionic charge carriers in the $\mathrm{CO}_{2}$ cell will need to be further investigated.

\section{$\mathrm{CO}_{2}$ Cell Performance}

Conducting long term tests of any electrochemical cells is the key in determining the performance and stability of all the cell components, particularly membranes and the anode/cathode catalysts. Here we discuss some of the long term performance of the DM laboratory 5 and $250 \mathrm{~cm}^{2} \mathrm{CO}_{2}$ electrolyzer cells.

\section{$5.0 \mathrm{~cm}^{2} \mathrm{CO}_{2}$ Cell Long Term Performance}

The $\mathrm{DM} \mathrm{CO}_{2}$ cell testing program employs numerous cells, evaluating different Sustainion ${ }^{\circledR}$ anion membrane compositions as well as anode and cathode composition configurations for operational periods of up to $4,000 \mathrm{~h}$ and more to ensure that the desired cell membrane and catalyst configuration performance is stable. Cell operation details and data have been detailed in 


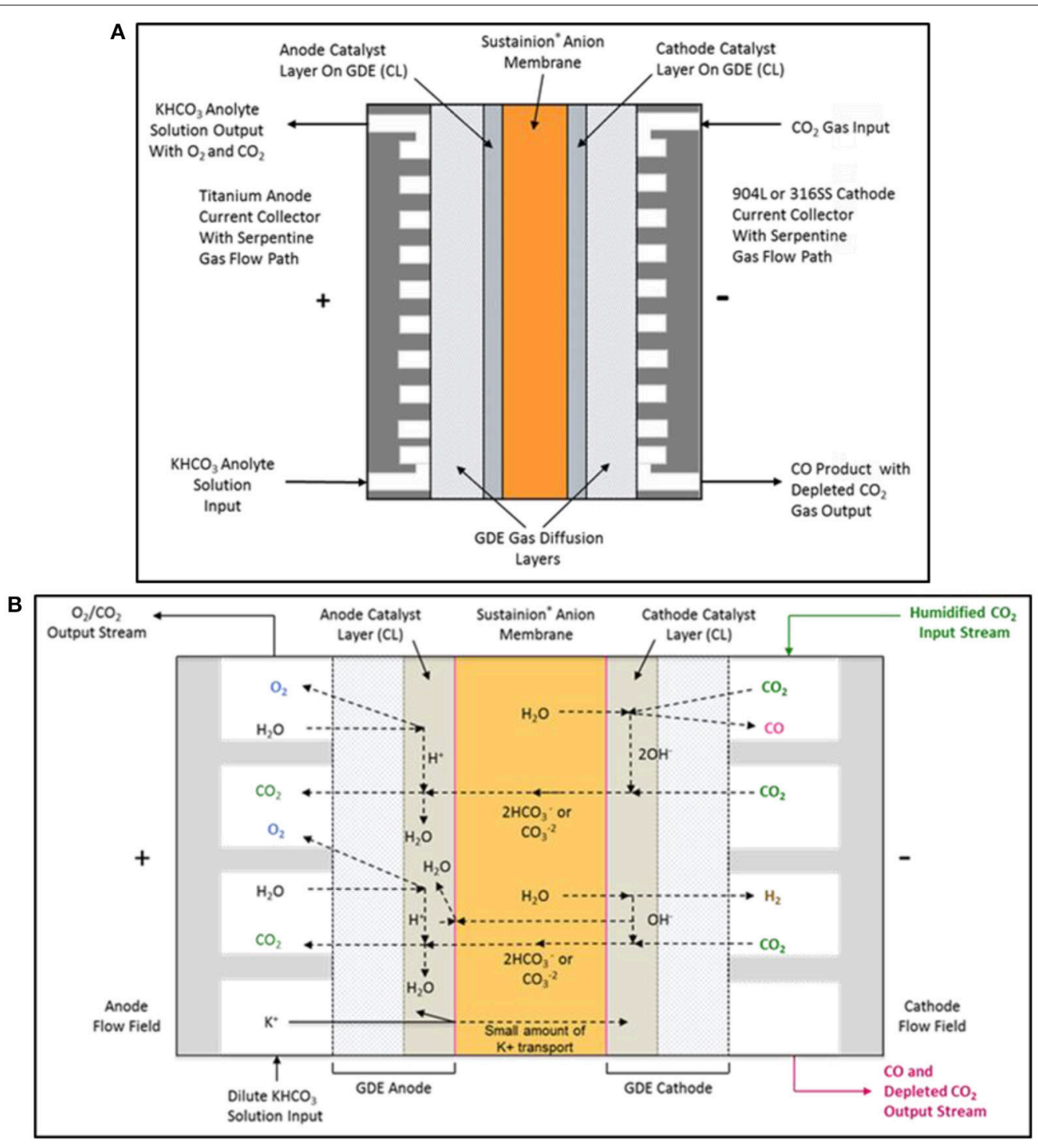

FIGURE 6 | The DM electrochemical $\mathrm{CO}_{2}$ cell configuration is shown in (A). The proposed electrochemical $\mathrm{CO}_{2}$ cell internal chemistry showing the main reactions and ionic specie flow paths are shown in (B).

several papers (Rosen et al., 2013; Liu et al, 2015; Masel and Chen, 2015). An example of a $5.0 \mathrm{~cm}^{2}$ cell long term test run for $4,000 \mathrm{~h}$ is shown in Figure 7A. A cell voltage polarization plot for the 5 $\mathrm{cm}^{2} \mathrm{CO}_{2}$ cell operating at room temperature $\left(24^{\circ} \mathrm{C}\right)$ is shown in Figure 7B.

\section{$250 \mathrm{~cm}^{2}$ Design $\mathrm{CO}_{2}$ Cell Performance}

The $5.0 \mathrm{~cm}^{2} \mathrm{CO}_{2}$ cell was subsequently scaled-up to a cell having a geometric active area of $250 \mathrm{~cm}^{2}$. In addition to testing at DM, one cell was sent to LanzaTech (Skokie, IL) for comparative testing. Table 4 shows the cell configuration details. The cell at DM was operated for a total of $760 \mathrm{~h}$ until shut down in preparation for further test work at LanzaTech. Figure 8A shows the cell operating performance at DM showing a stable voltage range of $2.9-3.0 \mathrm{~V}$ over the test period. The cell operating current density was $120 \mathrm{~mA} / \mathrm{cm}^{2}$, with an anolyte operating temperature of about $45^{\circ} \mathrm{C}$, without the need for any external cooling.

\section{$250 \mathrm{~cm}^{2} \mathrm{CO}_{2}$ Cell Test Operation at LanzaTech}

The $250 \mathrm{~cm}^{2} \quad \mathrm{CO}_{2}$ cell operation at LanzaTech helped in confirming the $\mathrm{CO}_{2}$ cell $\mathrm{CO}$ selectivity performance and gas product compositions. Figure $\mathbf{8 B}$ shows the test results of the $90 \mathrm{~h}$ test run. LanzaTech employed an automated Agilent Technologies Model 490 Micro GC with a Mol Sieve 5A (MS5A) column to analyze and monitor the cell catholyte gas product composition automatically over time. The outlier points are occasional analysis blips in the GC analysis. The cell CO selectivity ranged from 
TABLE 3 | Summary of reactions having (A) bicarbonate or (B) carbonate as the selected mobile anion specie through the anion membrane in the $\mathrm{CO}_{2}$ cell.

\begin{tabular}{ll}
\hline A. BICARBONATE & \\
Cathode: & $\mathrm{CO}_{2}+\mathrm{H}_{2} \mathrm{O}+2 \mathrm{e}^{-} \rightarrow \mathrm{CO}+2 \mathrm{OH}^{-}$ \\
& $+2\left[\mathrm{CO}_{2}+\mathrm{OH}^{-} \rightarrow \mathrm{HCO}_{3}^{-}\right]$ \\
Net Cathode: & $3 \mathrm{CO}_{2}+\mathrm{H}_{2} \mathrm{O}+2 \mathrm{e}^{-} \rightarrow \mathrm{CO}+2 \mathrm{HCO}_{3}^{-}$ \\
Anode: & $2 \mathrm{H}_{2} \mathrm{O} \rightarrow \mathrm{O}_{2}+4 \mathrm{H}^{+}+4 \mathrm{e}^{-}$ \\
& $+4\left[\mathrm{HCO}_{3}^{-}+\mathrm{H}^{+} \rightarrow \mathrm{CO}_{2}+\mathrm{H}_{2} \mathrm{O}\right]$ \\
Net Anode: & $4 \mathrm{HCO}_{3}^{-} \rightarrow 4 \mathrm{CO}_{2}+2 \mathrm{H}_{2} \mathrm{O}+\mathrm{O}_{2}$ \\
Overall Net: & $2 \mathrm{CO}_{2} \rightarrow 2 \mathrm{CO}+\mathrm{O}_{2}$ \\
B. CARBONATE & \\
Cathode: & $\mathrm{CO}_{2}+\mathrm{H}_{2} \mathrm{O}+2 \mathrm{e}^{-} \rightarrow \mathrm{CO}+2 \mathrm{OH}^{-}$ \\
& $+\mathrm{CO}_{2}+2 \mathrm{OH}^{-} \rightarrow \mathrm{CO}_{3}^{-2}+\mathrm{H}_{2} \mathrm{O}$ \\
Net Cathode: & $2 \mathrm{CO}_{2}+2 \mathrm{e}^{-} \rightarrow \mathrm{CO}^{-} \mathrm{CO}_{3}^{-2}$ \\
Anode: & $2 \mathrm{H}_{2} \mathrm{O} \rightarrow \mathrm{O}_{2}+4 \mathrm{H}^{+}+4 \mathrm{e}^{-}$ \\
& $+2\left[\mathrm{CO}_{3}^{-2}+2 \mathrm{H}^{+} \rightarrow \mathrm{CO}_{2}+\mathrm{H}_{2} \mathrm{O}\right]$ \\
Net Anode: & $2 \mathrm{CO}_{3}^{-2} \rightarrow 2 \mathrm{CO}_{2}+\mathrm{O}_{2}+4 \mathrm{e}^{-}$ \\
Overall Net: & $2 \mathrm{CO}_{2} \rightarrow 2 \mathrm{CO}^{-} \mathrm{O}_{2}$ \\
\hline
\end{tabular}

$97.5 \%$ (i.e., $1 \% \mathrm{H}_{2}$ content) to about $99 \% \quad\left(0.38 \% \quad \mathrm{H}_{2}\right.$ content).

\section{$250 \mathrm{~cm}^{2} \mathrm{CO}_{2}$ Cell Operating System}

Figure 9a shows the $250 \mathrm{~cm}^{2} \mathrm{CO}_{2}$ cell experimental test system configuration. Figures $\mathbf{9 b , c}$ show the Fuel Cell Technologies cell that was modified for use in the DM $250 \mathrm{~cm}^{2} \mathrm{CO}_{2}$ cell design. The left photo Figure $9 \mathrm{~b}$ shows the entire cell and right photo Figure 9c shows the titanium serpentine anode flow field design that was fabricated for the cell. $\mathrm{CO}_{2}$ gas was metered using a $\mathrm{CO}_{2}$ gas flow controller and bubbled through a water filled gas humidifier tank. The humidified $\mathrm{CO}_{2}$ gas enters the top of the $\mathrm{CO}_{2}$ cell cathode and exits at the bottom as a depleted $\mathrm{CO}_{2}$ gas stream containing the $\mathrm{CO}$ product and a small amount of byproduct $\mathrm{H}_{2}$. Excess condensed water is collected and separated from the gas stream product. The typical gas product from the $\mathrm{CO}_{2}$ cell was mainly $\mathrm{CO}$ with a small amount of byproduct $\mathrm{H}_{2}$ and operating with a stoichiometric excess of $\mathrm{CO}_{2}$. The cell $\mathrm{CO}$ selectivity ranged from about 95 to $99 \%$ depending on the applied current density and amount of excess $\mathrm{CO}_{2}$ over stoichiometric used in the catholyte gas feed as shown in Figure 8. The anolyte loop consists of a $10 \mathrm{mM} \mathrm{KHCO}_{3}$ electrolyte, having a conductivity of about $1.0 \mathrm{mS}$, which was pumped through the cell GDE anode at selected flowrates. A heat exchanger was used to control the anolyte loop temperature by controlling the flow of cooling water. A conductivity controller was used to control the addition of a concentrated $\mathrm{KHCO}_{3}$ solution to the anolyte loop as needed to maintain anolyte conductivity.

\section{$\mathrm{CO}_{2}$ Cell Scale-Up Progress}

Work on scale-up of the $\mathrm{DM} \mathrm{CO} \mathrm{CO}_{2}$ cell is continuing with other partners. In addition to scale-up, development work is proceeding in finding suitable stable non-precious metal catalyst replacements for the nanoparticle $\mathrm{IrO}_{2}$ used in the anode GDE design.
An estimate of the $\mathrm{CO}_{2}$ cell process power consumption, using the $250 \mathrm{~cm}^{2}$ cell data of $2.95 \mathrm{~V}$ at $30 \mathrm{amps}\left(120 \mathrm{~mA} / \mathrm{cm}^{2}\right)$ with $98 \%$ CO selectivity, was calculated to be $5.8 \mathrm{DC} \mathrm{kWh} / \mathrm{kg}$ of CO at $45^{\circ} \mathrm{C}$.

\section{ALKALINE WATER ELECTROLYSIS}

Alkaline water electrolysis is recognized as a mature technology that is reliable and safe, with electrolyzers having operational lifetimes as long as 15 years. Their biggest advantage is that they employ abundant, non-precious metal electrode catalysts. The conventional alkaline water electrolyzer cell design typically uses a diaphragm type separator. The separator typically requires that the distance between the anode and cathode electrodes to be about $2-3 \mathrm{~mm}$ apart to prevent gas crossover, thus limiting the operating current density to about $200 \mathrm{~mA} / \mathrm{cm}^{2}$ in order to operate at a reasonable operating voltage and corresponding overall energy efficiency. In order to increase the current density, while maintaining the same or higher energy efficiency, the next technology step would be to develop stable alkaline stable anion exchange membranes that would allow true zero-gap water electrolyzers. DM has developed alkaline water electrolyzer technology based on the development of a stable anion exchange membrane. The development work is summarized in various published papers and patents (Pletcher and Li, 2011; Deavin et al., 2012; Appel, 2013; Rosen et al., 2013; Masel et al., 2016b; Kutz et al., 2017; Liu et al., 2017a,b).

\section{DM Alkaline Water Electrolyzer Cell Design}

The development of an alkaline stable Sustainion ${ }^{\circledR}$ anion exchange membrane has enabled the development of zerogap design $\mathrm{CO}_{2}$ electrolyzers that can actually improve current density by an order of magnitude at the same or lower cell voltage as compared to the current diaphragm-based alkaline water electrolyzers. In order to test Sustainion ${ }^{\circledR}$ anion exchange membrane in a water electrolyzer configuration, a decision was made to use a similar cell design, Figures 9A,B, as employed in the $\mathrm{CO}_{2}$ electrolyzer, but using 316L stainless, or more preferred, pure nickel 200 flow fields in both the cathode and anode designs.

\section{Alkaline Electrolysis Cell Chemistry}

The alkaline water electrolysis cell operates using a $1 \mathrm{M} \mathrm{KOH}$ electrolyte solution at temperatures from ambient to $60^{\circ} \mathrm{C}$. Operation at $60^{\circ} \mathrm{C}$ provides the lowest operating cell voltage using the current Sustainion ${ }^{\circledR}$ anion exchange membranes to separate the anode and cathode reactions.

\section{Alkaline Electrolysis Cell Electrode Reactions}

Sustainion ${ }^{\circledR}$ membranes, which are prepared in the chloride $\left(\mathrm{Cl}^{-}\right)$form, need to be converted to the hydroxide $\left(\mathrm{OH}^{-}\right)$form. This is done by soaking in $1 \mathrm{M} \mathrm{KOH}$ for at least $12 \mathrm{~h}$. In the presence of a $\mathrm{KOH}$ electrolyte, both cathode and anode are operating at a local $\mathrm{pH}$ is close to 14 . At the cathode, the hydrogen evolution reaction (HER) uses water as proton donor, producing hydrogen and $\mathrm{OH}^{-}$(Equation 6). $\mathrm{OH}^{-}$ions transport from 

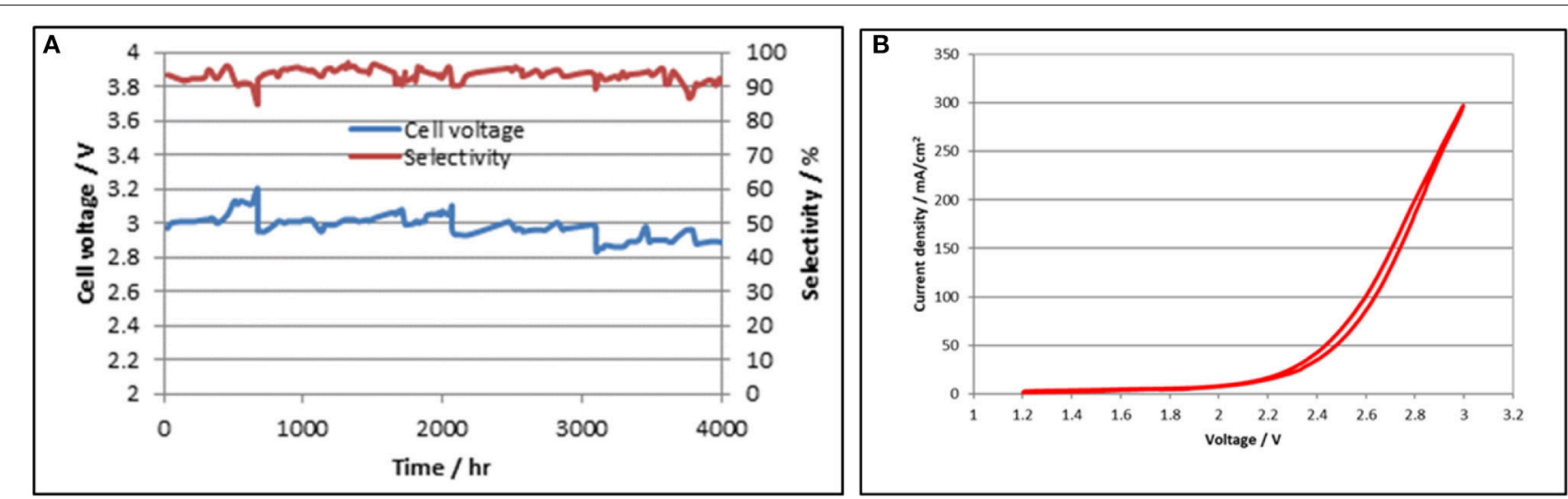

FIGURE 7 | $5.0 \mathrm{~cm}^{2}$ long term cell test data showing stable performance for $4,000 \mathrm{~h}$ is shown on the left in (A). A cell voltage polarization plot for the $5.0 \mathrm{~cm}^{2} \mathrm{CO}_{2}$ cell operating at room temperature is shown on the right in (B).

TABLE 4 | $250 \mathrm{~cm}^{2} \mathrm{CO}_{2}$ cell configuration details.

\section{$250 \mathrm{~cm}^{2}$ cell construction details:}

- Fuel Cell Technologies, Model 250SCH, modified with titanium anode and graphite flow fields

- DM Sustainion® T ePTFE reinforced membrane (88 $\mu$ m wet thickness)

- Anode GDE: $\mathrm{IrO}_{2}$ on 5\% CFP (carbon fiber paper)

- Cathode GDE: Nanoparticle Ag/Sustainion® ionomer on Sigracet 39BC paper

Operation:

- Anolyte solution flow: $200 \mathrm{~mL} / \mathrm{min}, 10 \mathrm{mM} \mathrm{KHCO}_{3}$

- $\mathrm{CO}_{2}$ gas rate: $1,000 \mathrm{~mL} / \mathrm{min}$, hydrated with water vapor

cathode to anode and recombine at the anode to generate $\mathrm{O}_{2}$ and electrons (Equation 14). The overall reaction is written in Equation 21.

$$
\begin{array}{ll}
4 \mathrm{H}_{2} \mathrm{O}+4 \mathrm{e}^{-} \rightarrow 2 \mathrm{H}_{2}+4 \mathrm{OH}^{-} & \mathrm{E}_{\mathrm{c}}^{0}=0.826 \mathrm{~V} \text { vs SHE } \\
4 \mathrm{OH}^{-} \rightarrow \mathrm{O}_{2}+2 \mathrm{H}_{2} \mathrm{O}+4 \mathrm{e}^{-} & \mathrm{E}_{\mathrm{a}}^{0}=-0.404 \mathrm{~V} \text { vs SHE } \\
2 \mathrm{H}_{2} \mathrm{O} \rightarrow 2 \mathrm{H}_{2}+\mathrm{O}_{2} & \mathrm{E}^{0}=1.23 \mathrm{~V}
\end{array}
$$

\section{Laboratory Alkaline Water Electrolysis Test System}

Figure 10A shows a general diagram of a DM $5 \mathrm{~cm}^{2}$ experimental alkaline water electrolysis operating system. The bottom of electrochemical cell anolyte and catholyte compartments are separately fed a pumped stream of $1 \mathrm{M} \mathrm{KOH}$ from a common gas disengagement $1 \mathrm{M} \mathrm{KOH}$ solution reservoir. Both the anolyte and catholyte compartment solution/gas product streams are separately routed to the individual $\mathrm{O}_{2}$ and $\mathrm{H}_{2}$ gas disengager sections of the gas/liquid disengager unit. The $\mathrm{O}_{2}$ and $\mathrm{H}_{2}$ gas products are separately vented from the disengager. One DM cell design uses silicone flexible strip heater pads mounted on the anode and cathode external plates to supply the heat for cell operation at $60^{\circ} \mathrm{C}$. The cell temperature is controlled using a PID temperature controller using a thermocouple mounted on the cell anode or cathode body.

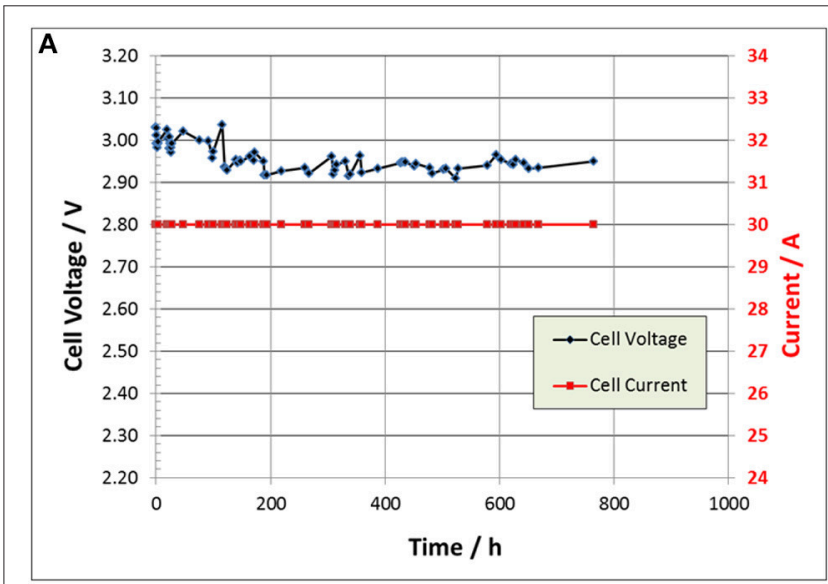

B

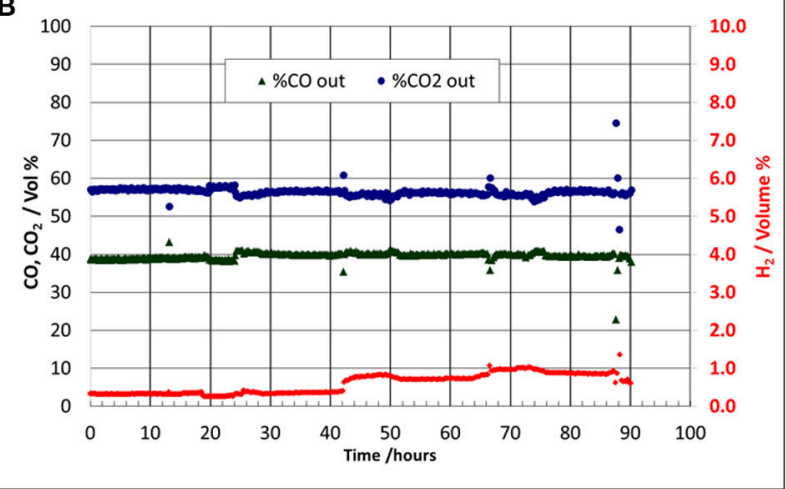

FIGURE 8 | The $250 \mathrm{~cm}^{2}$ cell performance at DM showing stable voltage operation for about $760 \mathrm{~h}$ until shutdown is shown in (A). The $250 \mathrm{~cm}^{2} \mathrm{CO}_{2}$ operation at LanzaTech shows the cell catholyte output GC gas composition analysis in an extended performance $90 \mathrm{~h}$ test run is shown in (B).

\section{Alkaline Water Electrolysis Cell Performance}

Figure 10B shows typical cyclic voltammogram of the alkaline water electrolyzer with a Sustainion ${ }^{\circledR}$ anion exchange membrane based on functionalization with 1-methyl imidazole. Pt and $\mathrm{IrO}_{2}$ 

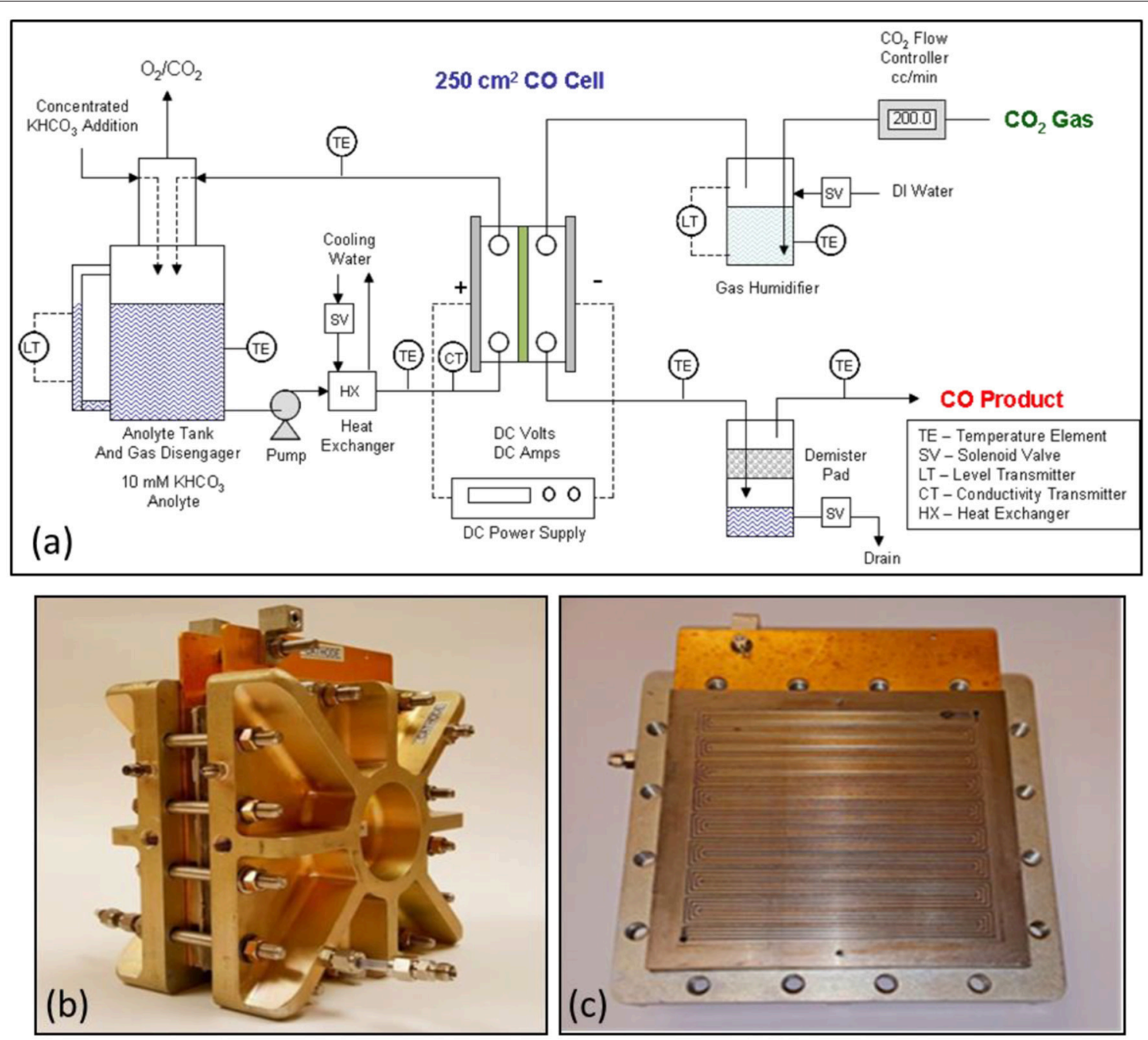

FIGURE 9 | Schematic of the $250 \mathrm{~cm}^{2} \mathrm{CO}_{2}$ cell experimental test system is shown in (a). The DM modified $250 \mathrm{~cm}^{2} \mathrm{CO}_{2}$ electrolyzer cell as shown in (b) on the left. The design used a titanium serpentine anode flow field design as shown in (c).

black were used as cathode and anode, respectively. The onset potential for water electrolysis with anion exchange membrane started at $1.42 \mathrm{~V}$, and the current increased quickly at a current density of $0.52 \mathrm{~A} / \mathrm{cm}^{2}$ (the maximum current of potentiostat) was $1.74 \mathrm{~V}$. The long term test was conducted at constant current of $0.8 \mathrm{~A} / \mathrm{cm}^{2}$ using a power supply, and the results are shown in Figure 10C. The cell voltage reached $2 \mathrm{~V}$ in $5 \mathrm{~min}$, and gradually increased to $2.3 \mathrm{~V}$ in $80 \mathrm{~min}$. The cell voltage then increased quickly and reached a cut off voltage of $3.5 \mathrm{~V}$ in less than $120 \mathrm{~min}$. These results showed that the 1-methyl imidazolebased membrane works in an alkaline water electrolyzer, but was not stable in $1 \mathrm{M} \mathrm{KOH}$. This was due to the three active hydrogen molecules in the imidazole ring that are attacked by hydroxyl radicals $(\cdot \mathrm{OH})$ in $1 \mathrm{M} \mathrm{KOH}$, especially at higher temperatures.

In order to improve the stability of anion exchange membrane, tetramethyl imidazole was grafted onto the styrene backbone instead of 1-methyl imidazole. This membrane was named
Sustainion ${ }^{\circledR} 37-50$. Figure 10C shows the polarization curves of the cell with Sustainion ${ }^{\circledR} 37-50$ membrane running in $1 \mathrm{M}$ $\mathrm{KOH}$ at $60^{\circ} \mathrm{C}$. The cell with Pt cathode and $\mathrm{IrO}_{2}$ anode achieved current densities of 1 and $3 \mathrm{~A} / \mathrm{cm}^{2}$ at 1.62 and $1.77 \mathrm{~V}$, respectively. As a comparison, the cell with $\mathrm{NiFeCo}$ cathode and $\mathrm{NiFeOx}$ anode reached 1 and $3 \mathrm{~A} / \mathrm{cm}^{2}$ at 1.90 and $2.13 \mathrm{~V}$, respectively. The cell with base metal/metal oxide electrodes and Sustainion ${ }^{\circledR}$ 37-50 anion exchange membranes achieved a 5-fold higher current density at $1.90 \mathrm{~V}$ than that $\left(200 \mathrm{~mA} / \mathrm{cm}^{2}\right.$ at $\left.2.0 \mathrm{~V}\right)$ of the commercial alkaline water electrolysis with diaphragms as separator.

Two questions were then needed to be answered. Does the Sustainion ${ }^{\circledR}$ anion exchange membrane have long term $\mathrm{KOH}$ stability and how long can it maintain performance? Figure 11A compares the cell performance of the Sustainion ${ }^{\circledR} 37-50$ anion exchange membrane with a commercial Fumatech FAS-50 anion exchange membrane in identical DM water electrolysis cells operating at a constant current density of $1 \mathrm{~A} / \mathrm{cm}^{2}$ in 


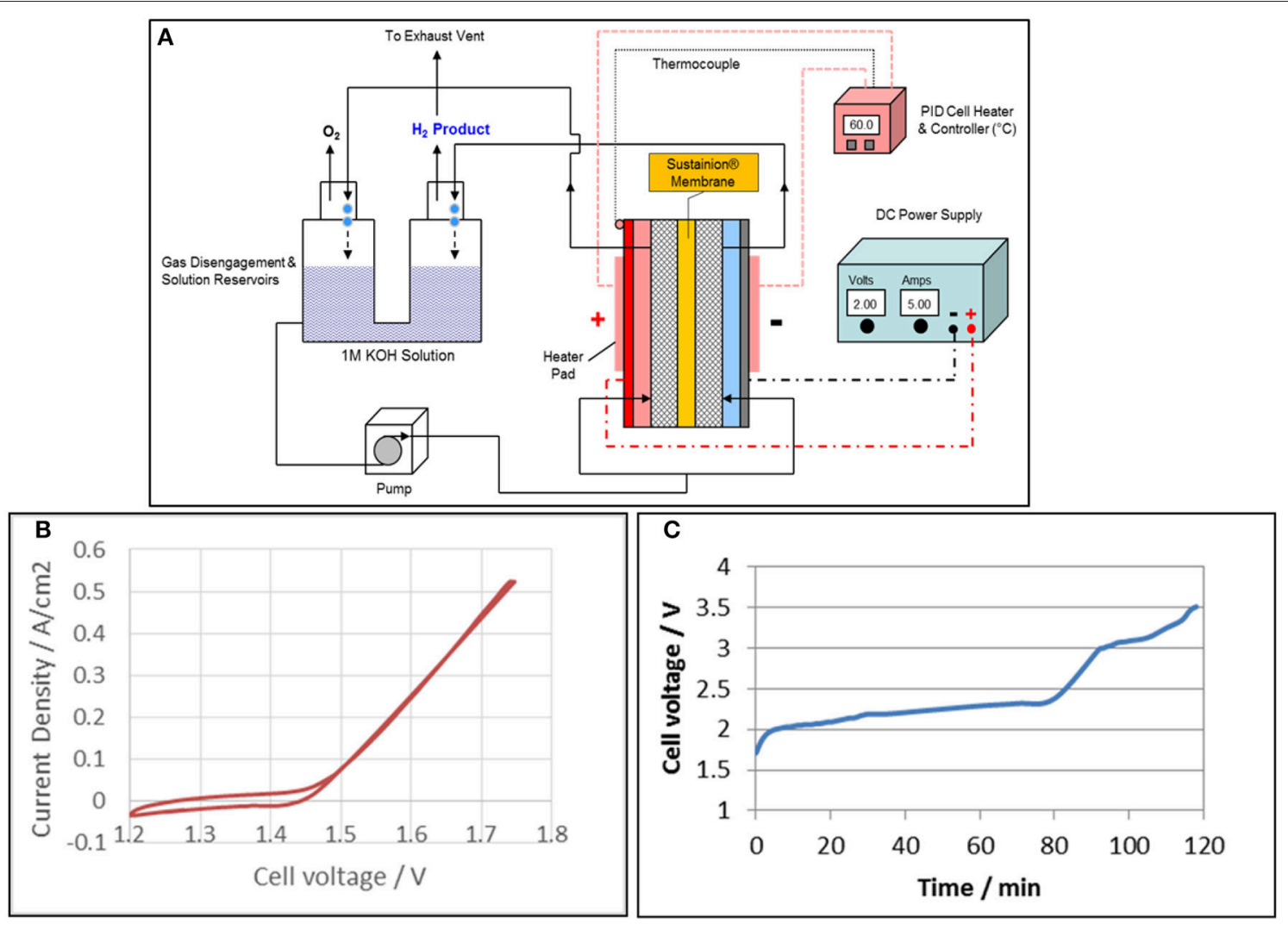

FIGURE 10 | Alkaline water electrolysis experimental test system for $5 \mathrm{~cm}^{2}$ test cells is shown in (A). A typical cyclic voltammogram of the alkaline water electrolyzer with a Sustainion ${ }^{\circledR}$ anion exchange membrane based on functionalization with 1-methyl imidazole is shown in (B) and the corresponding cyclic voltammogram is shown in (C). A Pt cathode and $\mathrm{IrO}_{2}$ anode were used and the cell was operated in $1 \mathrm{M} \mathrm{KOH}$ at $60^{\circ} \mathrm{C}$.

$1 \mathrm{M} \mathrm{KOH}$ at $60^{\circ} \mathrm{C}$. The results show that the Sustanion ${ }^{\circledR}$ membrane cell, operating at $1 \mathrm{~A} / \mathrm{cm}^{2}$ for almost $2,000 \mathrm{~h}$, had a cell voltage increase rate of only $5 \mu \mathrm{V} / \mathrm{h}$. This indicated that Sustainion ${ }^{\circledR}$ 37-50 anion exchange membrane functionalized with $1,2,4,5$-tetramethylimidazole was chemically very stable in $\mathrm{KOH}$ compared to the membrane functionalized with 1-methyl imidazole. This also confirmed that the instability of the 1methyl imidazole functionalized membrane was due to the active hydrogen in the ring. The Fumasep FAS- $50{ }^{\circledR}$ anion exchange membrane showed a significant increase of $200 \mu \mathrm{V} / \mathrm{h}$ in cell voltage over time and exhibited a high cell leakage current of 0.2 $\mathrm{A} / \mathrm{cm}^{2}$ at the $200 \mathrm{~h}$ point, and was then shut down.

Figure 11B shows alkaline electrolysis cell current at an applied potential of $2 \mathrm{~V}$ in evaluating the performance of various commercial membranes using a NiFeCo catalyst coated cathode and $\mathrm{NiFeOx}$ catalyst coated anode operating in $1 \mathrm{M} \mathrm{KOH}$ at $60^{\circ} \mathrm{C}$. The Sustainion ${ }^{\circledR}$ anion exchange membrane showed the highest cell current at the applied voltage. This compares with the membrane ASR membrane measurement data shown in Table 1.

Figure 11C shows the polarization curves of the same cell comparing precious metal electrode catalysts ( $\mathrm{Pt}$ on cathode $/ \mathrm{IrO}_{2}$ on anode) to base metal electrode catalysts (NiFe on anode/NiFeCo on cathode) using a Sustainion ${ }^{\circledR}$ 37-50 anion exchange membrane in $1 \mathrm{M} \mathrm{KOH}$ at $60^{\circ} \mathrm{C}$. At a current density of $1 \mathrm{~A} / \mathrm{cm}^{2}$, the cell using the precious metal catalysts operated at a cell voltage of $1.63 \mathrm{~V}$, and the base metal catalysts cell operated at $1.9 \mathrm{~V}$. The alkaline electrolysis cell CAPEX (capital expenditure) and OPEX (operating cost) which will need to include the availability/cost of both Ir and Pt catalysts in worldwide large scale installations then become important variables in the analysis decision for installing these systems.

\section{Alkaline Water Electrolysis Cell Scale-Up}

Commercial alkaline water electrolysis operate cells with electrode geometric areas varying from several hundred $\mathrm{cm}^{2}$ up to several $\mathrm{m}^{2}$. DM is now scaling up the zero-gap alkaline water electrolyzer design from $5 \mathrm{~cm}^{2}$ to larger $100-600 \mathrm{~cm}^{2}$ cells. In operating these larger alkaline water electrolyzers at high current densities of $1 \mathrm{~A} / \mathrm{cm}^{2}$ or more, both water and heat management are critically important. Based on energy and mass calculations, operating a $100 \mathrm{~cm}^{2}$ cell at $1 \mathrm{~A} / \mathrm{cm}^{2}$ and $1.90 \mathrm{~V}$, the water consumption would be about $806 \mathrm{~mL}$ per day with the generation of about $67 \mathrm{~W}$ of waste heat that has to be removed. The waste heat for a single cell can be handled with air cooling, but a large cell stack would require a recirculating cooling water system having a heat exchanger. A deionized water make-up system would be required for maintain the system liquid $\mathrm{KOH}$ electrolyte concentration and volume. 

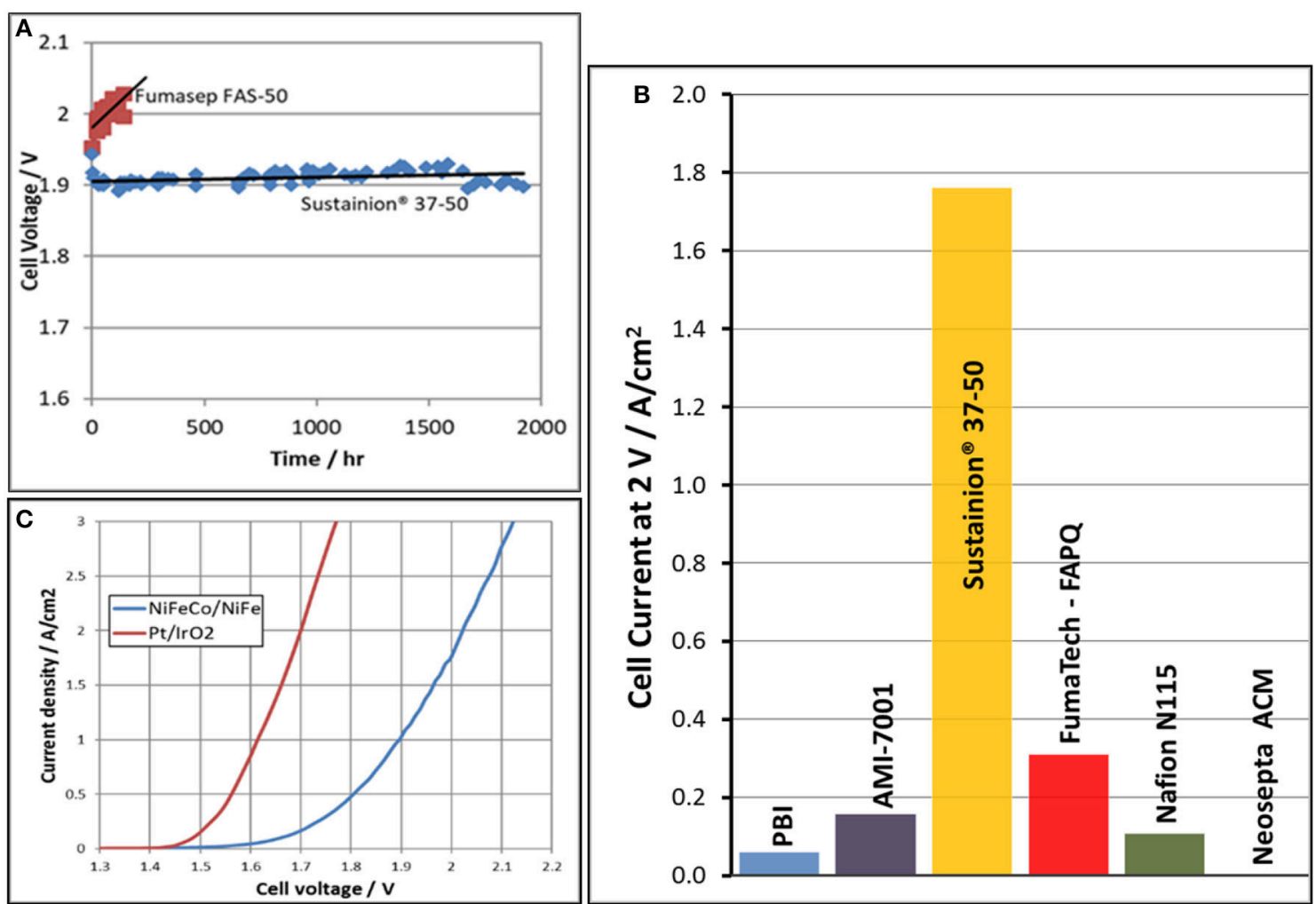

FIGURE 11 | Cell voltage as function of time comparison in cells evaluating a Sustainion ${ }^{\circledR} 37-50$ anion membrane and a Fumatech Fumasep ${ }^{\circledR}$ FAS-50 anion exchange membrane in $1 \mathrm{M} \mathrm{KOH}$ at $60^{\circ} \mathrm{C}$ is shown in (A). The alkaline electrolysis cell current at an applied voltage of $2 \mathrm{~V}$ for various membranes in $1 \mathrm{M} \mathrm{KOH}$ at $60^{\circ} \mathrm{C}$ is shown in (B). The polarization curves of the same cell comparing precious metal $\left(\mathrm{Pt} / \mathrm{r} \mathrm{O}_{2}\right)$ electrode catalysts to base metal electrode catalysts $(\mathrm{NiFeCo} / \mathrm{NiFe})$ in $1 \mathrm{M}$ $\mathrm{KOH}$ at $60^{\circ} \mathrm{C}$ using a Sustainion ${ }^{\circledR} 37-50$ anion exchange membrane is shown in (C).

The power consumption estimate for the alkaline water electrolysis cell, operating at $1 \mathrm{~A} / \mathrm{cm}^{2}$ at $1.90 \mathrm{~V}$, was calculated to be $50.5 \mathrm{DC} \mathrm{kWh} / \mathrm{kg} \mathrm{H}_{2}$. The electrolyzer energy consumption will be lower at lower operating current densities, but the capital costs for the electrolyzer cells will be significantly higher. All of these factors have to be considered when comparing the electrolyzer $\mathrm{H}_{2}$ power consumption to the DOE electrochemical hydrogen target goals which have stack energy efficiencies of $43 \mathrm{kWh} / \mathrm{kg}$ and hydrogen levelized cost of $\$ 2.00$ for 2020 (U.S. Department of Energy (DOE), 2018).

\section{SUMMARY}

Electrochemical technology in the conversion of $\mathrm{CO}_{2}$ to various products such as formic acid and CO as well as hydrogen using alkaline water electrolysis cells is advancing to commercialization with the development of the new Dioxide Materials Sustainion ${ }^{\circledR}$ anion exchange membranes. These membranes are both highly conductive and show excellent stability in highly alkaline solution environments at temperatures up to $60^{\circ} \mathrm{C}$. The electrochemical systems utilizing these new membranes are showing good stability in long term bench-scale tests over thousands of hours of operation. These anion exchange membranes are still in the development stage, and work is being done in improving the membrane mechanical and ionic conductivity properties.

Future work will focus on improvements in these anion exchange membranes as well as in the development of improved catalysts that will extend the performance of all these electrochemical technologies.

\section{AUTHOR CONTRIBUTIONS}

JK, HY, ZL, SS, and RM have all fully contributed to the content in this article. JK, HY, and SS worked in the development of the formic acid technology. ZL, SS, RM, and JK all worked on the alkaline water electrolysis technology. SS, ZL, and RM have all worked on the development of the Sustainion ${ }^{\circledR}$ anion exchange membrane development. ZL, HY, and RM have all worked on the development of the $\mathrm{CO}_{2}$ electrolysis technology. All have contributed to the content and editing of this article.

\section{ACKNOWLEDGMENTS}

Parts of this work were supported by DOE under contract DESC0004453 as well as in part by ARPA-E under contract DEAR0000684 and 3M company. The opinions here are those 
of the authors and may not reflect the opinions of DOE or $3 \mathrm{M}$. Assistance from DM colleagues, collaborators, and friends from $3 \mathrm{M}$ are gratefully acknowledged. In addition, special acknowledgment of support from LanzaTech, in particular
Sean Simpson (CSO and Founder), Christophe Mihalcea (Director, Fermentation), Bruce Li (Sr. Dev. Engr.), and Nick Bourdakos (Sr. Fermentation Engr.) in providing us their valuable experimental operating data on the $\mathrm{DM} \mathrm{CO}_{2}$ cell.

\section{REFERENCES}

Agarwal, A. S., Zhai, Y., Hill, D., and Sridhar, N. (2011). The Electrochemical reduction of carbon dioxide to formate/formic acid: engineering and economic feasibility. ChemSusChem 4, 1301-1310. doi: 10.1002/cssc.2011 00220

Alvarez-Guerra, M., Del Castillo, A., and Irabien, A. (2014). Continuous electrochemical reduction of carbon dioxide into formate using a tin cathode: comparison with lead cathode. Chem. Eng. Res. Des. 92, 692-701. doi: 10.1016/j.cherd.2013.11.002

Alvarez-Guerra, M., Quintanilla, S., and Irabien, A. (2012). Conversion of carbon dioxide into formate using a continuous electrochemical reduction process in a lead cathode. Chem. Eng. J. 207, 278-284. doi: 10.1016/j.cej.2012. 06.099

Appel, A. M., Bercaw, J. E., Bocarsly, A. B., Dobbek, H., DuBois, D. L., Dupuis, M. et al., (2013). Frontiers, opportunities, and challenges in biochemical and chemical catalysis of $\mathrm{CO}_{2}$ fixation. Chem. Rev. 113, 6621-6658. doi: $10.1021 / \mathrm{cr} 300463 \mathrm{y}$

Aresta, M. (2010). Carbon Dioxide as Chemical Feedstock. Weinheim: Wiley-VCH, $1-13$.

Aresta, M., and Dibenedetto,. A. (2007). Utilisation of $\mathrm{CO}_{2}$ as a chemical feedstock: opportunities and challenges. Dalton Trans. 28, 2975-2992. doi: 10.1039/b700658f

Aresta, M., Dibenedetto, A., and Quaranta, E. (2016). State of the art and perspectives in catalytic process for $\mathrm{CO}_{2}$ conversion into chemicals and fuels: the distinctive contribution of chemical catalysis and biotechnology. Catal. J. 343, 2-45. doi: 10.1016/j.jcat.2016.04.003

Costentin, C., Robert, M., and Savéant,. J. M. (2014). Catalysis of the electrochemical reduction of carbon dioxide. Chem. Soc. Rev. 42, 2423-2436. doi: $10.1039 / \mathrm{C} 2 \mathrm{CS} 35360 \mathrm{~A}$

Deavin, O. I., Murphy, S., Ong, A. L., Poynton, S. D., Zeng, R., and Varcoe, J. R. (2012). Anion-exchange membranes for alkaline polymerelectrolyte fuel cells: comparison of pendent benzyltrimethylammonium- and benzylmethylimidazolium-head-groups. Energy Environ. Sci. 5, 8584-8597. doi: 10.1039/C2EE22466F

Du, D., Lan, R., Humpheys, J., and Tao, S. (2017). Progress in inorganic cathode catalysts for electrochemical conversion of carbon dioxide into formate or formic acid. J.Appl. Electrochem. 47, 661-678. doi: 10.1007/s10800-017-1078-x

Du, D., Lan, R., Humphreys, J., Sengodan, S., Xie, K., Wang, H., et al., (2016). Achieving both high selectivity and current density for $\mathrm{CO}_{2}$ reduction to formate on nanoporous tin foam electrocatalysts. Chem. Sel. 1, 1711-1715. doi: 10.1002/slct.201600451

Halmann, M. M. (1993). Chemical Fixation of Carbon Dioxide: Methods for Recycling $\mathrm{CO}_{2}$ into Useful Products. Boca Raton, FL: CRC Press, 67-127.

Hu, B., Guild, C., and Suib, S. L. (2013). Thermal, electrochemical, and photochemical conversion of $\mathrm{CO}_{2}$ to fuels and value-added products. J. $\mathrm{CO}_{2}$ Util. 1, 18-27. doi: 10.1016/j.jcou.2013.03.004

Jitaru, M. (2007). Electrochemical carbon dioxide reduction - Fundamental and applied topics (Review). J. Univ. Chem. Technol. Metal. 42, 333-344. Available online at: http://dl.uctm.edu/journal/node/j2007-4/1_Jitaru_333-344.pdf

Kaczur, J. J., Yang, H., Sajjad, S. D., and Masel, R. I. (2017). Method and System for Electrochemical Production of Formic Acid from Carbon dioxide, Boca Raton, FL: U.S. Patent Application, 2017/0037522.

Kopljar, D., Inan, A., Vindayer, P., Wagner, N., and Klemm,. E. (2014). Electrochemical reduction of $\mathrm{CO}_{2}$ to formate at high current density using gas diffusion electrodes. J. Appl. Electrochem. 44, 1107-1116. doi: 10.1007/s10800-014-0731-x

Kutz, R. B., Chen, Q., Yang, H., Sajjad, S., D., Liu, Z., and Masel, I. R. (2017). Sustainion Imidazolium-Functionalized Polymers for $\mathrm{CO}_{2}$ Electrolysis. Energy Technol. 5, 929-936. doi: 10.1002/ente.201600636
Li, H., and Oloman, C. (2005). The electro-reduction of carbon dioxide in a continuous reactor. J. Appl. Electrochem. 35, 955-965. doi: 10.1007/s10800-005-7173-4

Li, H., and Oloman, C. (2006). Development of a continuous reactor for the electro-reduction of carbon dioxide to formate. part 1. Process variables. J. Appl. Electrochem. 36, 1105-1115. doi: 10.1007/s10800-006-9194-z

Li, H., and Oloman, C. (2007). Development of a continuous reactor for the electro-reduction of carbon dioxide to formate. Part 2. Scaleup. J. Appl. Electrochem. 37, 1107-1117. doi: 10.1007/s10800-007-9371-8

Liu, Z., Masel, R. I., Chen, Q., Kutz, R., Yang, H., Lutz, D. R. et al., (2015). Electrochemical generation of syngas from water and carbon dioxide at industrially important rates. J. $\mathrm{CO}_{2}$ Util. 15, 50-56. doi: 10.1016/j.jcou.2016.04.011

Liu, Z., Sajjad, S. D., Gao, Y., Yang, H., Kaczur, J. J., and Masel, R. I. (2017a). The effect of membrane on an alkaline water electrolyzer. Intl. J. Hydrogen Energy 42, 29661-29665. doi: 10.1016/j.ijhydene.2017.10.050

Liu, Z., Sajjad, S., D., Gao, Y., Kaczur, J., J., and Masel, R. I. (2017b). An alkaline water electrolyzer with Sustainion ${ }^{\mathrm{TM}}$ membranes: $1 \mathrm{~A} / \mathrm{cm}^{2}$ at $1.9 \mathrm{~V}$ with Base Metal Catalysts. ECS Trans. 77, 71-73. doi: 10.1149/07709.0071ecst

Lu, X., Leung, D. Y. C., Wang, H., Leung, M. K., H., and Xuan, J. (2014). Electrochemical reduction of carbon dioxide to formic acid. ChemElectroChem 1, 836-849. doi: 10.1002/celc.201300206

Mahmood, M. N., Masheder, D., and Harty, C. J. (1987). Use of gasdiffusion electrodes for high-rate electrochemical reduction of carbon dioxide. I. Reduction at lead, indium- and tin-impregnated electrodes. J. Appl. Electrochem. 17, 1159-1170. doi: 10.1007/BF01023599

Masel, R. I., and Chen, Q. (2015). Carbon Dioxide Conversion to Fuels and Chemicals. Boca Raton, FL. U.S. Patent 9,193,593.

Masel, R. I., Chen, Q., Liu, Z., and Kutz, R. (2017b). Ion-Conducting Membranes. Boca Raton, FL. U.S. Patent 9,580,824.

Masel, R. I., Chen, Q., Liu, Z., and Kutz, R. (2017c). Ion-Conducting Membranes. Boca Raton, FL. U.S. Patent 9,370,773.

Masel, R. I., Chen, Q., Liu, Z., and Kutz,. R. (2016c). Electrochemical Device for Converting Carbon Dioxide to a Reaction Product. Boca Raton, FL. U.S. Patent $9,481,939$.

Masel, R. I., Liu, Z., and Sajjad, S. (2016b). Anion exchange membrane electrolyzers showing $1 \mathrm{~A} / \mathrm{cm}^{2}$ at less than 2 V. ECS Trans. 75, 1143-1145. doi: $10.1149 / 07514.1143$ ecst

Masel, R. I., Ni, R., Liu, Z., Chen, Q., Kutz, R and Lewinski, K. (2014a). Unlocking the potential of $\mathrm{CO}_{2}$ conversion to fuels and chemicals as an economically viable route to CCR. Energy Proc. 63, 7959-7962. doi: 10.1016/j.egypro.2014.11.832

Masel, R. I., Rosen, B. A., and Zhu, W. (2014b). Devices and Processes for Carbon Dioxide Conversion into Useful Fuels and Chemicals. Boca Raton, FL. U.S. Patent 9,181,625

Masel, R. I., Sajjad, S., D., Gao, Y., Liu, Z., and Chen, Q. (2017a). Ion-Conducting Membranes. Boca Raton, FL. U.S. Patent 9,849,450.

Masel, R. I., Salahi-Khogin, A., and Rosen, B. A. (2015). Catalysts for Electrochemical Conversion of Carbon Dioxide. Boca Raton, FL. U.S. Patent $9,012,345$.

Masel, R. I., Shajjad, S. D., and Pellerite, M. J. (2017d). Method of Making an Anion Exchange Membrane. Boca Raton, FL. U.S. Patent Application 2017/0189898.

Masel, R., Liu, Z., Zhao, D., Chen, Q., Lutz, D., and Nereng, L. (2016a). " $\mathrm{CO}_{2}$ conversion to chemicals with emphasis on using renewable energy/resources to drive the conversion," in Commercializing Biobased Products: Opportunities, Challenges, Benefits, and Risks RSC Green Chemistry, No. 43, ed S. Snyder (Cambridge: Royal Society of Chemistry), 215-257. doi: 10.1039/9781782622444-00215

Masel, R.,I., and Rosen, B. A. (2014). A Catalyst Mixtures. Boca Raton, FL. U.S. Patent 8,956,990. 
Oloman, C., and Li, H. (2008). Electrochemical processing of carbon dioxide. ChemSusChem 1, 1385-1391. doi: 10.1002/cssc.200800015

Pellerite, M., Kaplun, M., Hartmann-Thompson, C., Lewinski, K., A., Kunz, N., Gregar, N., et al. (2017). Imidazolium-functionalized polymer membranes for fuel cells and electrolyzers. ECS Trans. 80, 945-956. doi: 10.1149/08008.0945ecst

Pletcher, D. (2015). The cathodic reduction of carbon dioxide - What can it realistically achieve? A mini review. Electrochem. Commun. 61, 97-101. doi: $10.1016 /$ j.elecom.2015.10.006

Pletcher, D., and Li, X. (2011). Prospects for alkaline zero gap water electrolyzers for hydrogen production. Int. J. Hydrogen Energy 36, 15089-15104. doi: 10.1016/j.ijhydene.2011.08.080

Qiao, J., Liu, Y., Hong, F., and Zhang, J. (2014). A review of catalysts for the electroreduction of carbon dioxide to produce low-carbon fuels. Chem. Soc. Rev. 43, 631-675. doi: 10.1039/C3CS60323G

Quadrelli, E. A., Centi, G., Duplan, J. L., and Perathoner, S. (2011). Carbon dioxide recycling: emerging large-scale technologies with industrial potential. ChemSusChem 4, 1194-1215. doi: 10.1002/cssc. 201100473

Rosen, B. A., Salehi-Kohjin, A., Thorsen, M., R., Zhu, W., Whipple, P. J. A., Kenis, P. J. A., and Masel, R. I. (2011). Ionic liquid-mediated selective conversion of $\mathrm{CO}_{2}$ to $\mathrm{CO}$ at low overpotentials. Science 334, 643-644. doi: 10.1126/science. 1209786

Rosen, B. A., Zhu, W., Kaul, G., Salehi-Khojin, A., and Masel, R. I. (2013). Water enhancement of $\mathrm{CO}_{2}$ conversion on silver in 1-Ethyl-3Methylimidazolium Tetrafluoroborate. J. Electrochem. Soc. 160, H138-H141. doi: $10.1149 / 2.004303$ jes

Sajjad, S., Gao, Y., Liu, Z., Yang, H., and Masel, R. (2017). Tunable-High performance sustainion ${ }^{\mathrm{TM}}$ anion exchange membranes for electrochemical applications. ECS Trans. 77, 1653-1656. doi: 10.1149/07711.1653ecst

Sankaranarayanan, S., and Srinivasan,. K. (2012). Carbon dioxide - a potential raw material for the production of fuel, fuel additives and bio-derived chemicals. Indian Chem. J. 51A, 1252-1262. Available Online at: http://nopr.niscair.res.in/ handle/123456789/14662

Sen, S., Skinn, B., Hall, T., Inman, M., Taylor, E. J., and, Brushett, F. R. (2016). Pulsed electrodeposition of tin electrocatalysts onto gas diffusion layers for carbon dioxide reduction to formate. MRS Adv. 2, 451-458. doi: $10.1557 /$ adv.2016.652

U.S. Department of Energy (DOE) (2018). DOE Targets for Hydrogen Production from Electrolysis, Office of Energy Efficiency and Renewable Energy, Fuel Cell
Technologies Office. Available online at: https://www.energy.gov/eere/fuelcells/ doe-technical-targets-hydrogen-production-electrolysis.

Ursua, A., Gandia, L. M., and Sanchis, P. (2012). Hydrogen Production from water electrolysis: current status and future trends. Proc. IEEE 100, 410-426. doi: 10.1109/JPROC.2011.2156750

Vengatesan, S., Santhi, S., Jeevanantham, S., and Sozhan, G. (2015). Quaternized poly (styrene-co-vinylbenzyl chloride) anion exchange membranes for alkaline water electrolyzers. J. Pow. Sources 284, 361-368. doi: 10.1016/j.jpowsour.2015.02.118

Whipple, D. T., and Kenis, P. J. A. (2010). Prospects of $\mathrm{CO}_{2}$ utilization via direct heterogeneous electrochemical reduction. J. Phys. Chem. Lett. 1, 3451-3458. doi: $10.1021 /$ jz1012627

Whipple, D. T., Finke, E. C., and Kenis, P. J. A. (2010). Microfluidic reactor for the electrochemical reduction of carbon dioxide: the effect of p H. Electrochem. Solid State Lett. 13, B109-B111. doi: 10.1149/1.3456590

White, J. L., Herb, J. T., Kaczur, J. J., Majsztrik, P. W., and Bocarsly, A. B. (2014). Photons to formate: efficient electrochemical solar energy conversion via reduction of carbon dioxide. J. $\mathrm{CO}_{2}$ Util. 7, 1-5. doi: 10.1016/j.jcou.2014.05.002

Yang, H., Kaczur, J. J., Sajjad, S. D., and Masel, R. I. (2017a). Electrochemical conversion of $\mathrm{CO}_{2}$ to formic acid utilizing sustainion ${ }^{\mathrm{R}}$ membranes. J. $\mathrm{CO}_{2}$ Util. 20, 208-217. doi: 10.1016/j.jcou.2017.04.011

Yang, H., Kaczur, J., Sajjad, S. D., and Masel, R. I. (2017b). $\mathrm{CO}_{2}$ Conversion to formic acid in a three compartment cell with sustainion ${ }^{\mathrm{TM}}$ membranes. ECS Trans. 77, 1425-1431. doi: 10.1149/07711.1425ecst

Conflict of Interest Statement: The authors have submitted several patents on the membranes and designs disclosed here including US 9,370,773, US 9,481,939, US 9,580,824, and US patent applications $15 / 400,775,15 / 406,909,15 / 411,831$. The authors are all employees of Dioxide Materials and have a financial interest in these patents. Dioxide Materials is offering all of our research materials (membranes, catalysts etc.) for sale to other research groups so that they can reproduce and build on the findings.

Copyright $\odot 2018$ Kaczur, Yang, Liu, Sajjad and Masel. This is an open-access article distributed under the terms of the Creative Commons Attribution License (CC BY). The use, distribution or reproduction in other forums is permitted, provided the original author(s) and the copyright owner(s) are credited and that the original publication in this journal is cited, in accordance with accepted academic practice. No use, distribution or reproduction is permitted which does not comply with these terms. 